\title{
Development of a Coordinatively Unsaturated Chiral Indenylruthenium Catalyst
}

\author{
Barry M. Trost, Michael C. Ryan, and David Maurer \\ Department of Chemistry, Stanford University, Stanford, CA 94305-5080 \\ Supporting Information
}

\section{Table of Contents}

I. Screening Table For Indenylmetal addition to Arene Ruthenium

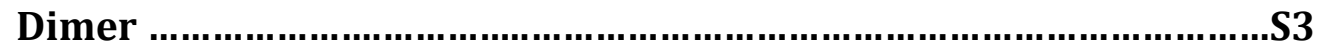

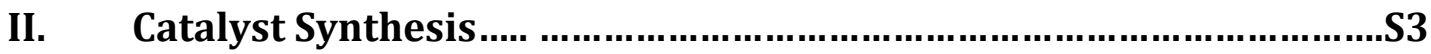

III. Enyne Cycloisomerization and Hydroxycyclization..........................S8

IV. Redox Isomerization/C-H Insertion.............................................

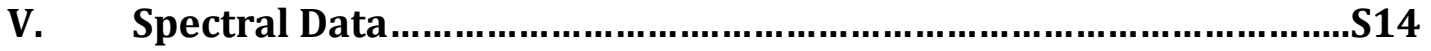




\section{Experimental Details}

All reactions were performed in flame- or oven-dried glassware with magnetic stirring under a nitrogen or argon atmosphere using freshly distilled or column-dried solvents. All other commercial reagents were used without purification unless otherwise noted. Air and moisture sensitive liquids and solutions were transferred via stainless steel syringe or cannula and introduced into the reaction vessel through rubber septa. Reactions conducted below room temperature were cooled by an external bath: dry ice in acetone for $-78{ }^{\circ} \mathrm{C}$ or ice in water for $0 \circ \mathrm{C}$. Thin-layer chromatography was performed on EMD silica gel 60 F254 plates $(0.25 \mathrm{~mm})$; visualization of the developed chromatogram was performed by fluorescence quenching and staining with aqueous ceric ammonium molybdate, $p$ - anisaldehyde, or potassium permanganate. Organic solutions were concentrated by rotary evaporation below $40{ }^{\circ} \mathrm{C}$ at ca. $25 \mathrm{~mm} \mathrm{Hg}$. Chromatographic purification of products was accomplished using forced-flow chromatography on silica gel (particle size $0.040-0.063 \mathrm{~mm}$ ). All isolated and characterized compounds were $>90 \%$ pure as judged by $1 \mathrm{H}-\mathrm{NMR}$ spectroscopic analysis unless noted otherwise. $1 \mathrm{H}$ and $13 \mathrm{C}$ NMR spectroscopy were performed on a $400 \mathrm{MHz}$ NMR spectrometer Varian Mercury console Sun Blade 100 operating at 400 (1H) and $100 \mathrm{MHz}(13 \mathrm{C})$, respectively, as well as on a $300 \mathrm{MHz}$ NMR spectrometer Varian Inova console Sun Sparcstation 5 operating at $300(1 \mathrm{H})$ and $75 \mathrm{MHz}(13 \mathrm{C})$, respectively. Chemical shifts are reported in ppm relative to residual protio solvent signals; all 13C NMR spectra are proton decoupled. Data for $1 \mathrm{H}$ are reported as chemical shift $(\delta \mathrm{ppm})$, multiplicity $(\mathrm{s}=$ singlet, $\mathrm{d}=$ doublet, $\mathrm{t}=$ triplet, $\mathrm{q}=$ quartet, quint = quintet, sex $=$ sextet, sept $=$ septet, oct $=$ octet, $\mathrm{m}=$ multiplet, app. $=$ apparent $),$ coupling constant integration); data for $13 \mathrm{C}$ are reported in terms of chemical shift. Infrared spectroscopic data was recorded on sodium chloride plates as thin films on a Thermo Scientific Nicolet IR100 FT-IR spectrometer. Mass spectrometry data were collected by LC/ESI-MS on a Waters Acquity UPLC and Thermo Fisher Exactive mass spectrometer scanning m/z 100-1200. The LC conditions were 95\% Solvent A $(0.1 \%$ formic acid in water) held 1 minute then ramped to $98 \%$ Solvent B $(0.1 \%$ formic acid in acetonitrile) in 2 minutes, and held for 3 minutes. The column was a $2.1 \times 30 \mathrm{~mm}$ Zorbax C18 $3.5 \mathrm{um}$ and the flow rate was $0.4 \mathrm{~mL} / \mathrm{min}$. Chiral HPLC analysis was performed on a Thermo Separation Products Spectra Series P-100 using Chiralcel R and Chiralpak R columns. 


\section{Screening Table For Indenylmetal addition to Arene Ruthenium Dimer}

\begin{tabular}{|c|c|c|c|c|c|c|c|c|}
\hline Entry & Indene & Base & Solvent A & Temp A $\left({ }^{\circ} \mathrm{C}\right)$ & Ru Dimer & Solvent B & Temp A $\left({ }^{\circ} \mathrm{C}\right)$ & Result \\
\hline 1 & S1 & $\mathrm{LiOtBu}$ & THF & 50 & {$\left[\left(\mathrm{C}_{6} \mathrm{H}_{6}\right) \mathrm{RuCl}_{2}\right]_{2}$} & THF & -78 to r.t. & trace \\
\hline 2 & S2 & TIOEt & $\mathrm{Et}_{2} \mathrm{O}$ & r.t. & {$\left[\left(\mathrm{C}_{6} \mathrm{H}_{6}\right) \mathrm{RuCl}_{2}\right]_{2}$} & THF & r.t & No reaction \\
\hline 3 & S2 & TIOEt & THF & r.t. & {$\left[\left(\mathrm{C}_{6} \mathrm{H}_{6}\right) \mathrm{RuCl}_{2}\right]_{2}$} & $\mathrm{MeCN}$ & r.t & No reaction \\
\hline 4 & S3 & NaHMDS & THF & 0 & {$\left[\left(\mathrm{C}_{6} \mathrm{H}_{6}\right) \mathrm{RuCl}_{2}\right]_{2}$} & THF & r.t. & $20 \%$ yield \\
\hline 5 & S3 & $\mathrm{KH}$ & THF & 0 to r.t. & {$\left[\left(\mathrm{C}_{6} \mathrm{H}_{6}\right) \mathrm{RuCl}_{2}\right]_{2}$} & THF & r.t. & $50 \%$ yield \\
\hline 6 & S3 & $\mathrm{KH}$ & THF & 0 to r.t. & {$\left[(p \text {-cymene }) \mathrm{RuCl}_{2}\right]_{2}$} & THF & r.t. & $50 \%$ yield \\
\hline 7 & S3 & $\mathrm{KH}$ & THF & 0 to r.t. & {$\left[\left(\mathrm{C}_{6} \mathrm{Me}_{6}\right) \mathrm{RuCl}_{2}\right]_{2}$} & THF & r.t. & No reaction \\
\hline $8^{a}$ & S3 & $\mathrm{KH}$ & THF & 0 to r.t. & {$\left[\left(\mathrm{C}_{6} \mathrm{H}_{6}\right) \mathrm{RuCl}_{2}\right]_{2}$} & THF & r.t. & No Reacton \\
\hline 9 & S2 & $\mathrm{KH}$ & THF & 0 to r.t. & {$\left[\left(\mathrm{C}_{6} \mathrm{H}_{6}\right) \mathrm{RuCl}_{2}\right]_{2}$} & DMSO & r.t. & Decomposition \\
\hline 10 & S2 & $\mathrm{KH}$ & THF & 0 to r.t. & {$\left[\left(\mathrm{C}_{6} \mathrm{H}_{6}\right) \mathrm{RuCl}_{2}\right]_{2}$} & $\mathrm{MeCN}$ & r.t. & Decomposition \\
\hline $11^{b}$ & S2 & $\mathrm{K}_{2} \mathrm{CO}_{3}$ & $\mathrm{~N} / \mathrm{A}$ & $\mathrm{N} / \mathrm{A}$ & {$\left[\left(\mathrm{C}_{6} \mathrm{H}_{6}\right) \mathrm{RuCl}_{2}\right]_{2}$} & $\mathrm{EtOH}$ & 60 & Decomposition \\
\hline $12^{b}$ & S2 & $\mathrm{K}_{2} \mathrm{CO}_{3}$ & $\mathrm{~N} / \mathrm{A}$ & $N / A$ & {$\left[(p \text {-cymene }) \mathrm{RuCl}_{2}\right]_{2}$} & $\mathrm{EtOH}$ & 60 & Decomposition \\
\hline $13^{b}$ & S2 & $\mathrm{K}_{2} \mathrm{CO}_{3}$ & $\mathrm{~N} / \mathrm{A}$ & $\mathrm{N} / \mathrm{A}$ & {$\left[(\mathrm{COD}) \mathrm{RuCl}_{2}\right]_{\mathrm{n}}$} & $\mathrm{EtOH}$ & 60 & Decomposition \\
\hline
\end{tabular}

a Potassium indenide transmetalated with 0.5 eq. of $\mathrm{ZnCl}_{2}$ before $\mathrm{Ru}$ dimer addition.

b No preincubation period for indene and base; all components combined in one flask before heating. 3 eq. indene used.

\section{Catalyst Synthesis}

(S)-1-bromo-8-(p-anisylsulfinyl)naphthalene (8)

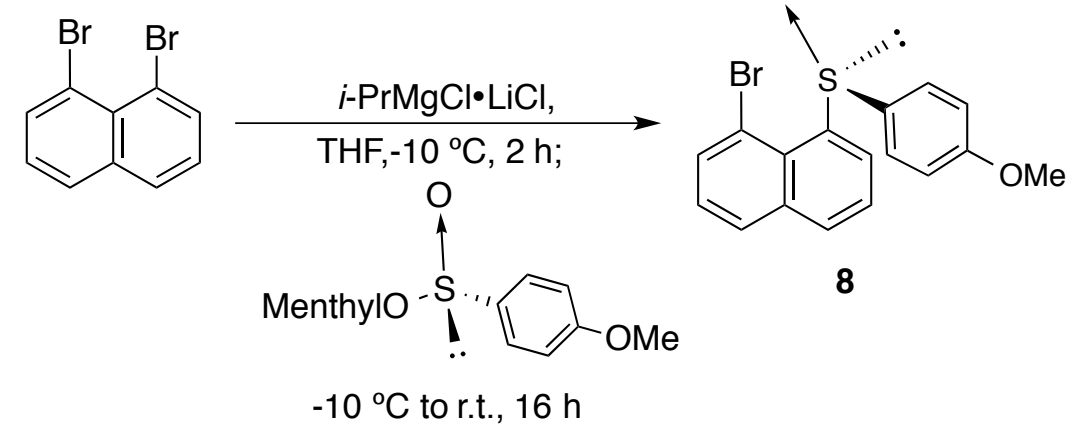

A two-neck $25 \mathrm{ml}$ round-bottomed flask with stir bar was charged with $\mathrm{LiCl}$ (146 mg, $3.45 \mathrm{mmol}, 1.05$ eq.) and flame-dried. The flask was placed under nitrogen and $i \mathrm{PrMgCl}$ was added via syringe (1.67 M in THF, $2.07 \mathrm{~mL} 3.45 \mathrm{mmol}, 1.05$ eq.). This 
solution was allowed to stir at room temperature for 1 hour (complete consumption of the $\mathrm{LiCl}$ observed). This solution was cooled to $-10{ }^{\circ} \mathrm{C}$ using a brine/ice bath and a solution of 1,8-dibromonaphthalene in THF (940 mg, $3.29 \mathrm{mmol}, 1$ eq. in $6.90 \mathrm{~mL}$ THF) was added via syringe. This reaction was allowed to stir at $-10{ }^{\circ} \mathrm{C}$ for 2 hours. After 2 hours a solution of $p$-anisolesulfinate menthyl ester $(1.07 \mathrm{~g}, 3.45 \mathrm{mmol}, 1.05 \mathrm{eq}$ in 4.47 $\mathrm{mL}$ THF) was added via syringe. The reaction was warmed to room temperature and allowed to stir for 16 hours. The reaction was then quenched with sat. aq. $\mathrm{NH}_{4} \mathrm{Cl}(4$ $\mathrm{mL})$ and $\mathrm{Et}_{2} \mathrm{O}(4 \mathrm{~mL})$. The layers were separated and the aqueous phase was washed with $\mathrm{Et}_{2} \mathrm{O}(3 \mathrm{x} 4 \mathrm{~mL})$. The combined organics were dried over $\mathrm{MgSO}_{4}$, filtered, and concentrated. The crude reaction mixture was purified via silica gel chromatography (2:1 hexanes:EtOAc) to give $(S)$-1-bromo-8-( $p$-anisylsulfinyl)naphthalene 8 as a viscous brown oil (1.14 g, $3.15 \mathrm{mmol}, 96 \%$ yield). [ $\mathrm{R}_{\mathrm{f}}=0.07$ (3:1 hexanes:EtOAc)]; $[\alpha]_{\mathrm{D}}{ }^{25}=-352.87^{\circ}\left(1.0, \mathrm{CHCl}_{3}\right)$; IR (thin film) $v_{\max }=3066,2939,2837,1592,1576,1549$, 1494, 1461, 1441, 1408, 1354, 1331, 1303, 1256, 1176, 1148, 1110, 1079, 1040, 961, 912, 822, 797, 755, 731; ${ }^{1} \mathrm{H}-\mathrm{NMR}\left(500 \mathrm{MHz}^{\mathrm{CDCl}} 3\right): \delta 8.77(\mathrm{~d}, J=7.5 \mathrm{~Hz}, 1 \mathrm{H}), 7.97$ (d, $J$ $=8.1 \mathrm{~Hz}, 1 \mathrm{H}), 7.88(\mathrm{~d}, J=8.1 \mathrm{~Hz}, 1 \mathrm{H}), 7.74(\mathrm{dt}, J=18.5,8.7 \mathrm{~Hz}, 2 \mathrm{H}), 7.40(\mathrm{~d}, J=8.9 \mathrm{~Hz}$, 2H), $7.28(\mathrm{dd}, J=16.0,8.2 \mathrm{~Hz}, 1 \mathrm{H}), 6.79(\mathrm{~d}, J=8.9 \mathrm{~Hz}, 2 \mathrm{H}), 3.70(\mathrm{~s}, 3 \mathrm{H}) ;{ }^{13} \mathrm{C}-\mathrm{NMR}(101$ $\mathrm{MHz}_{\mathrm{CDCl}}$ ): $\delta$ 161.26, 141.97, 138.50, 136.50, 136.47, 134.15, 132.46, 129.20, 128.88, 126.68, 126.10, 125.92, 117.45, 114.39, 55.29; LR-MS (m/z): $\left[\mathrm{M}+\mathrm{H}^{+}\right]$calcd for $\mathrm{C}_{17} \mathrm{H}_{14} \mathrm{BrO}_{2} \mathrm{~S}: 360.1$; found: 360.1.; HR-MS (m/z): [M + $\left.\mathrm{Na}^{+}\right]$calcd for $\mathrm{C}_{17} \mathrm{H}_{13} \mathrm{BrNaO}_{2} \mathrm{~S}$ : 382.9717; found: 382.9717.

2-(1H-inden-2-yl)-4,4,5,5-tetramethyl-1,3,2-dioxaborolane (9)

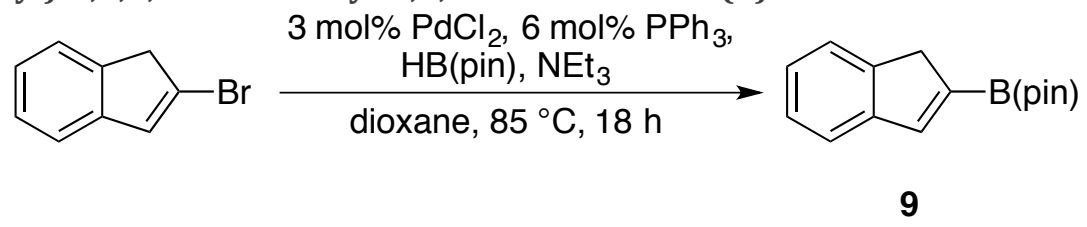

A $250 \mathrm{~mL}$ round bottom flask with stir bar was flame-dried and charged with $\mathrm{PdCl}_{2}$ (83 mg, $0.47 \mathrm{mmol}, 0.03$ eq.), $\mathrm{PPh}_{3}$ (247 mg, $0.94 \mathrm{mmol}, 0.06$ eq.), fitted with a septum, and placed under nitrogen. Dioxane $(62.4 \mathrm{~mL})$, triethylamine $(655 \mathrm{~mL}, 47$ mmol, 3 eq.), and 2-bromoindene (3.05 g, $15.6 \mathrm{mmol}, 1$ eq.) was added via syringe and the solution was sparged with argon for 15 minutes. HB(pin) (3.34 mL, $23.4 \mathrm{mmol}, 1.5$ 
eq.) was added via syringe (caution-gas evolution!). The solution was heated to $85{ }^{\circ} \mathrm{C}$ in an oil bath for 18 hours. After 18 hours, the reaction was cooled to room temperature and quenched with $100 \mathrm{~mL}$ of sat. aq. $\mathrm{NaCl}$. The layers were separated and the aqueous phase was extracted with ether (3x $50 \mathrm{~mL})$. The combined organics were dried over $\mathrm{MgSO}_{4}$, filtered, and concentrated. The crude material was purified via silica gel chromatography (20:1 hexanes:Et ${ }_{2} 0$ ) to yield 9 as an off-white solid (2.59 g, $10.7 \mathrm{mmol}, 69 \%$ yield). M.P. $=65-66{ }^{\circ} \mathrm{C} ;{ }^{1} \mathrm{H}-\mathrm{NMR}\left(400 \mathrm{MHz} ; \mathrm{CDCl}_{3}\right): \delta 7.57(\mathrm{td}, J=2.0$, $0.8 \mathrm{~Hz}, 1 \mathrm{H}), 7.51-7.45(\mathrm{~m}, 2 \mathrm{H}), 7.28-7.22(\mathrm{~m}, 2 \mathrm{H}), 3.54(\mathrm{~s}, 2 \mathrm{H}), 1.33(\mathrm{~s}, 12 \mathrm{H})$. The remaining spectral data matched literature values. ${ }^{1}$

(S)-1-(1H-inden-2-yl)-8-(p-anisylsulfinyl)naphthalene (7)

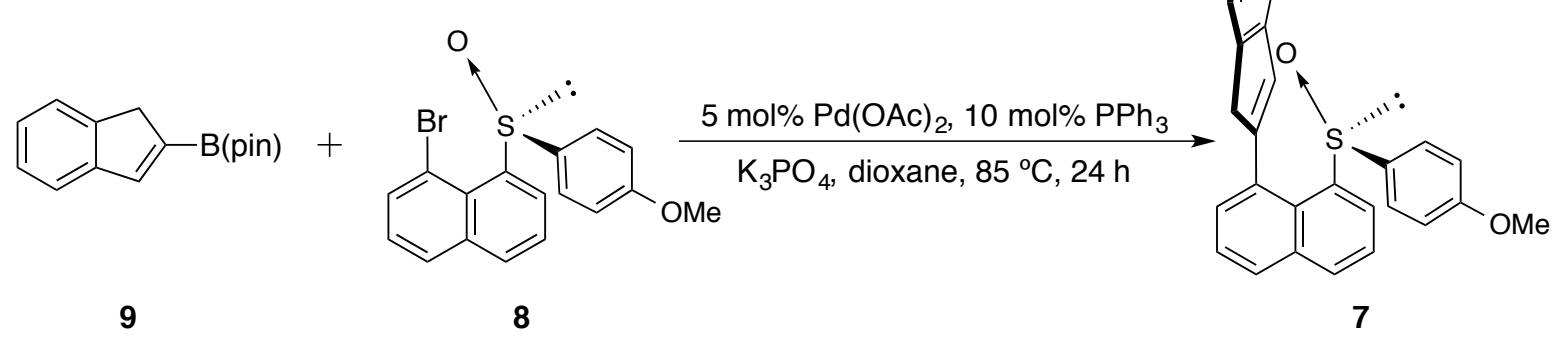

Bromide 8 (135 mg, $0.37 \mathrm{mmol}, 1$ eq.), boronic ester 9 (99 mg, $0.41 \mathrm{mmol}, 1.1$ eq.), $\mathrm{Pd}(\mathrm{OAc})_{2}$ ( $5 \mathrm{mg}, 0.019 \mathrm{mmol}, 0.05 \mathrm{eq}$ ), $\mathrm{PPh}_{3}(10 \mathrm{mg}, 0.038 \mathrm{mmol}, 0.1 \mathrm{eq}$ ), and $\mathrm{K}_{3} \mathrm{PO}_{4}$ (236 mg, $1.11 \mathrm{mmol}, 3$ eq.) were all added to a flame-dried $25 \mathrm{~mL}$ pear shaped flask with stir bar. The flask was fitted with a septum and placed under argon. Dioxane (1.23 mL) was added and the solution was sparged for 15 minutes. After 15 minutes, the reaction was heated to $85^{\circ} \mathrm{C}$ for 24 hours. After 24 hours, the reaction was cooled to room temperature and filtered through a plug of silica using $\mathrm{Et}_{2} \mathrm{O}$ as the eluent. The filtrate was concentrated in vacuo. The crude material was purified via silica gel chromatography (4:1 hex:EtOAc) to give (S)-1-(1H-inden-2-yl)-8-( $p$ anisylsulfinyl)naphthalene 7 as a tan solid ( $80 \mathrm{mg}, 0.2 \mathrm{mmol}, 54 \%$ yield). [ $\mathrm{R}_{\mathrm{f}}=0.8$ (4:1 hexanes:EtOAc)]; M.P. $=138-139{ }^{\circ} \mathrm{C} ;[\alpha]_{\mathrm{D}} 25=-723.62^{\circ}\left(1.0, \mathrm{CH}_{2} \mathrm{Cl}_{2}\right)$; IR (thin film) $v_{\max }=$ $3057,3001,2838,1592,1575,1495,1461,1442,1408,1390,1361,1302,1255,1212$, $1176,1109,1082,1030,826,797,755,717,692,665 ;{ }^{1} \mathrm{H}-\mathrm{NMR}\left(400 \mathrm{MHz} ; \mathrm{CDCl}_{3}\right): \delta$

\footnotetext{
${ }^{1}$ Lee, D.-W; Yun, J. -S. Bulletin of the Korean Chemical Society 2004, 25 (1), 29.

2 Ramón Rodríguez, J.; Castedo, L.; Mascareñas, J. L. J. Org. Chem. 2000, 65 (8), 2528.
} 
8.71-8.56 (m, 1H), $8.10(\mathrm{~d}, J=7.8 \mathrm{~Hz}, 1 \mathrm{H}), 7.94(\mathrm{~d}, J=7.7 \mathrm{~Hz}, 1 \mathrm{H}), 7.78(\mathrm{t}, J=7.7 \mathrm{~Hz}, 1 \mathrm{H})$, $7.51(\mathrm{t}, J=7.6 \mathrm{~Hz}, 2 \mathrm{H}), 7.37-7.26(\mathrm{~m}, 3 \mathrm{H}), 6.94-6.81(\mathrm{br}, 2 \mathrm{H}), 6.83-6.52(\mathrm{br}, 3 \mathrm{H}), 6.30-$ 6.22 (br, 1H), 4.15-4.04 (br, 1H), 3.73 (s, 3H), 3.55-3.36 (br, 1H); ${ }^{13} \mathrm{C}-\mathrm{NMR}(101 \mathrm{MHz}$, $\left.\mathrm{CDCl}_{3}\right): \delta 161.53,144.46,144.41,143.99,143.97,134.55,133.16,132.43,129.28$, 128.92, 128.87, 126.66, 125.76, 125.47, 125.25, 123.98, 121.39, 121.29, 114.41, 114.19, 114.13, 55.34, 45.27; LR-MS (m/z): [M + $\left.\mathrm{H}^{+}\right]$calcd for $\mathrm{C}_{26} \mathrm{H}_{21} \mathrm{O}_{2} \mathrm{~S}: 397.1$; found: 397.2; HR-MS (m/z): [M + Na+] calcd for $\mathrm{C}_{26} \mathrm{H}_{20} \mathrm{NaO}_{2} \mathrm{~S}: 419.1082$; found: 419.1082 .
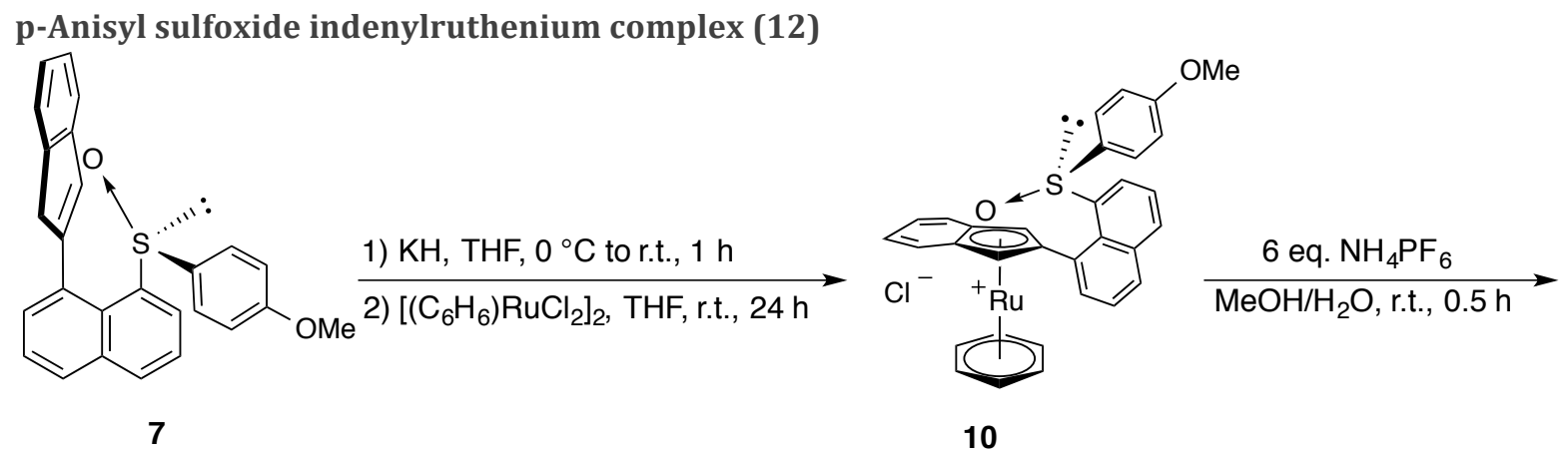

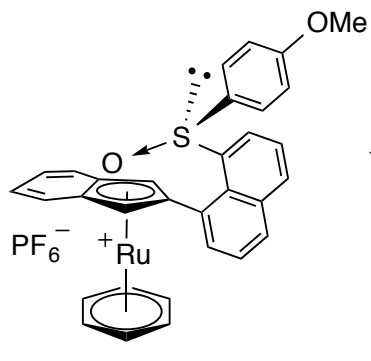

11

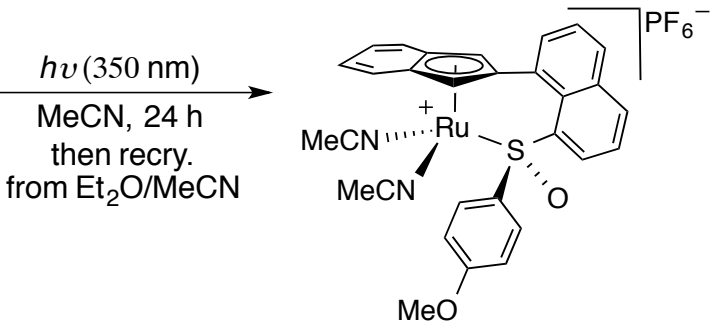

12

An oven-dried $25 \mathrm{~mL}$ round bottomed flask with stir bar was brought into the glovebox and charged with potassium hydride $(13 \mathrm{mg}, 0.31 \mathrm{mmol}, 1.2 \mathrm{eq}$.). The flask was fitted with a septum and brought out of the glovebox. An argon balloon was fitted to the flask via syringe needle and the flask was placed in an ice bath. A solution of indene 7 (113 mg, $0.28 \mathrm{mmol}, 1.1 \mathrm{eq}$ ) in THF (1.75 mL) was taken up via syringe and added dropwise to the $\mathrm{KH}$ over 5 minutes. After the addition was completed, the ice bath was removed and the reaction stirred at room temperature for $1 \mathrm{~h}$. The color of the solution turned to black-red indicating indene deprotonation. A second $25 \mathrm{~mL}$ pear-shaped flask with stir bar was flame-dried and charged with $\left[\left(\mathrm{C}_{6} \mathrm{H}_{6}\right) \mathrm{RuCl}_{2}\right]_{2}(63$ $\mathrm{mg}, 0.25 \mathrm{mmol}, 1$ eq., calculated as the monomer). This flask was also placed under 
argon. THF (5 mL) was added to this flask via syringe. The potassium indenide solution was taken up via syringe and added to the dimer mixture at room temperature. The reaction was allowed to stir at room temperature for $24 \mathrm{~h}$. After 24 $\mathrm{h}$, the reaction was concentrated in vacuo, diluted with DCM, filtered through celite, and concentrated in vacuo. The crude material was purified via acidic alumina chromatography (1\% to $3 \%$ to $5 \% \mathrm{MeOH}$ in DCM) to yield complex $\mathbf{4 1 0}$ as a brown foamy solid (36 mg, $0.059 \mathrm{mmol}, 24 \%$ yield). This complex was used directly in the ion exchange.

Complex 10 (46 mg, $0.075 \mathrm{mmol}, 1$ eq.) was dissolved in $0.75 \mathrm{~mL}$ of a 1:1 v/v mixture of water/methanol. Ammonium hexafluorophosphate (74 mg, $0.45 \mathrm{mmol}, 6$ eq.) was added in one portion and the reaction was allowed to stir at room temperature for $15 \mathrm{~min}$. $1.5 \mathrm{~mL}$ of DCM was added, and the layers were shaken and separated. The organic phase was washed twice with DCM (2x $1.5 \mathrm{~mL})$. The combined organics were dried over magnesium sulfate, filtered, and concentrated to yield $\mathbf{1 1}$ as a brown foamy solid (38 mg, $0.053 \mathrm{mmol}, 71 \%$ yield). $[\alpha]_{\mathrm{D}}^{25}=-263.25^{\circ}\left(1.0, \mathrm{CD}_{3} \mathrm{CN}\right)$; IR (thin film) $v_{\max }=2881,1568,1473,1422,1285,1240,1160,1065,1023,829,756 ;{ }^{1} \mathrm{H}-$ NMR (400 MHz; CD $3 \mathrm{CN}): \delta 8.42(\mathrm{dd}, J=7.3,1.3 \mathrm{~Hz}, 1 \mathrm{H}), 8.16(\mathrm{dd}, J=8.1,1.2 \mathrm{~Hz}, 1 \mathrm{H})$, $8.06(\mathrm{dd}, J=8.2,1.1 \mathrm{~Hz}, 1 \mathrm{H}), 7.79-7.70(\mathrm{~m}, 3 \mathrm{H}), 7.61-7.57(\mathrm{~m}, 2 \mathrm{H}), 7.42-7.39(\mathrm{~m}, 2 \mathrm{H})$, $6.67(\mathrm{~d}, J=8.9 \mathrm{~Hz}, 2 \mathrm{H}), 6.55(\mathrm{~s}, 1 \mathrm{H}), 6.47(\mathrm{~d}, J=8.9 \mathrm{~Hz}, 2 \mathrm{H}), 6.06(\mathrm{~s}, 1 \mathrm{H}), 5.71(\mathrm{~s}, 6 \mathrm{H})$, 3.68 (s, 3H); ${ }^{13} \mathrm{C}-\mathrm{NMR}\left(101 \mathrm{MHz}, \mathrm{CD}_{3} \mathrm{CN}\right): \delta$ 162.90, 141.78, 136.92, 135.67, 135.49, $133.57,131.77,130.85,130.73,129.25,127.88,127.68,126.88,126.79,126.75,126.71$, 126.68, 115.46, 109.15, 98.41, 97.96, 88.64, 79.99, 78.54, 56.21; ${ }^{19} \mathrm{~F}-\mathrm{NMR}$ (376 MHz, $\left.\mathrm{CD}_{3} \mathrm{CN}\right): \delta$-73.22; HR-MS (m/z): [M - $\mathrm{PF}_{6}$ ] calcd for $\mathrm{C}_{32} \mathrm{H}_{25} \mathrm{O}_{2} \mathrm{RuS}$ : 575.0613; found: 575.0627.

Mixed sandwich complex 1 (38 mg, $0.053 \mathrm{mmol}, 1$ eq.) was dissolved in $26.5 \mathrm{~mL}$ of acetonitrile (0.002 M solution) and added to large test tubes. The test tubes were fitted with septa and wrapped with electrical tape. The complex solutions were sparged with argon before being placed into a Rayonet Photochemical Reactor (equipped with F8T5-BL blacklight lamps, irradiating at $350 \mathrm{~nm}$ ) and irradiated for 24 h. After 24 hours, the reaction was concentrated in vacuo to yield $\mathbf{1 2}$ as a bright yellow 
solid (20 mg, $0.028 \mathrm{mmol}, 53 \%$ yield). $[\alpha]_{\mathrm{D}}^{25}=-139.40^{\circ}\left(0.5, \mathrm{CH}_{3} \mathrm{CN}\right)$; IR (thin film) $v_{\max }=3726,37083697,3647,3625,3593,3566,3357,2958,1635,1590,1541,1492$, 1344, 1305, 1256, 1173, 1101, 1067, 1024, 837, 797, 764, 678, 669, 649, 594, 584, 557, 532; ${ }^{1} \mathrm{H}-\mathrm{NMR}\left(400 \mathrm{MHz} ; \mathrm{CD}_{3} \mathrm{CN}\right): \delta 8.40(\mathrm{~d}, J=7.5 \mathrm{~Hz}, 1 \mathrm{H}), 8.12(\mathrm{~d}, J=7.1 \mathrm{~Hz}, 1 \mathrm{H}), 8.04$ (d, $J=7.1 \mathrm{~Hz}, 1 \mathrm{H}), 7.83$ (d, $J=5.8 \mathrm{~Hz}, 1 \mathrm{H}), 7.76(\mathrm{~d}, J=7.6 \mathrm{~Hz}, 1 \mathrm{H}), 7.70-7.62(\mathrm{~m}, 2 \mathrm{H})$, 7.58-7.57 (m, 2H), $7.50(\mathrm{~m}, J=2.8 \mathrm{~Hz}, 1 \mathrm{H}), 7.44(\mathrm{~d}, J=9.1 \mathrm{~Hz}, 2 \mathrm{H}), 6.86(\mathrm{~d}, J=9.1 \mathrm{~Hz}$, 2H), $5.55(\mathrm{~s}, 1 \mathrm{H}), 4.80(\mathrm{~s}, 1 \mathrm{H}), 3.75(\mathrm{~s}, 3 \mathrm{H}) ;{ }^{13} \mathrm{C}-\mathrm{NMR}\left(101 \mathrm{MHz}, \mathrm{CD}_{3} \mathrm{CN}\right): \delta$ 181.87, 161.89, 141.94, 135.14, 133.94, 131.76, 130.96, 129.99, 129.23, 126.82, 126.17, 125.97, $125.76,124.74,124.38,123.92,114.17,109.13,105.74,97.24,62.13,56.79,55.60 ;{ }^{19} \mathrm{~F}-$ NMR $\left(376 \mathrm{MHz}, \mathrm{CD}_{3} \mathrm{CN}\right): \delta$-73.27; LR-MS (m/z): [M - $\left.\mathrm{PF}_{6}-2 \mathrm{MeCN}\right]$ calcd for $\mathrm{C}_{26} \mathrm{H}_{19} \mathrm{O}_{2} \mathrm{RuS}$ : 497.0; found: 497.1; HR-MS (m/z): [M - $\mathrm{PF}_{6}$ ] calcd for $\mathrm{C}_{30} \mathrm{H}_{25} \mathrm{O}_{2} \mathrm{RuS}$ : 579.0675; found: 579.0688 .

\section{Enyne Cycloisomerization and Hydroxycyclization}

(7-methyloct-6-en-1-yne-4,4-diyldisulfonyl)dbenzene (13)
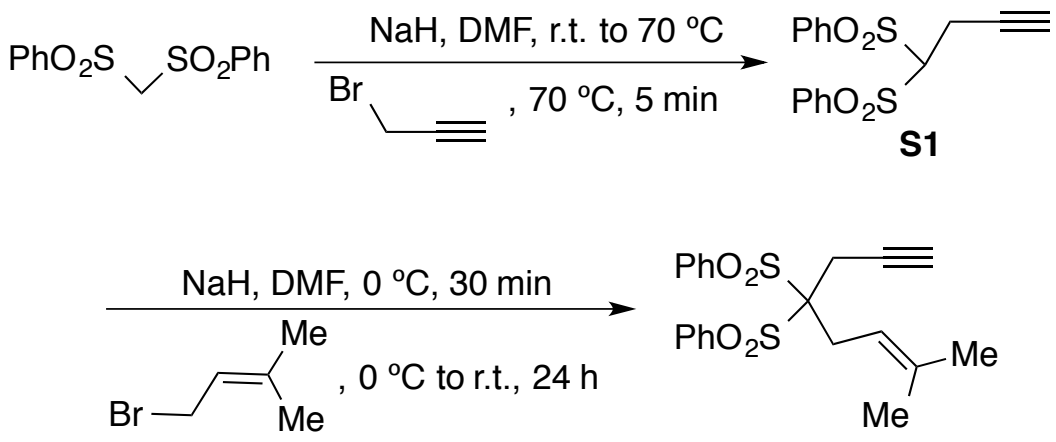

13

A $50 \mathrm{~mL}$ round bottom flask with stir bar was flame-dried and charged with sodium hydride ( $60 \mathrm{wt} \%$ in mineral oil, $440 \mathrm{mg}, 11 \mathrm{mmol}, 1.1 \mathrm{eq}$.). The flask was placed under an atmosphere of argon. A separate $25 \mathrm{~mL}$ pear-shaped flask was flamedried, charged with bis(phenylsulfonyl)methane (2.96 g, $10 \mathrm{mmol}, 1 \mathrm{eq}$ ), and placed under argon. The sulfone was dissolved in $16.7 \mathrm{~mL}$ of dry DMF, added via syringe. The solution of sulfone was then added to the flask containing sodium hydride via syringe. The reaction was allowed to stir at room temperature for 5 minutes before it was 
heated to $70{ }^{\circ} \mathrm{C}$ in an oil bath. Propargyl bromide ( $80 \mathrm{wt} \%$ in toluene, $1.18 \mathrm{~mL}, 10.6$ mmol, 1.06 eq.) was added rapidly via syringe and the reaction was allowed to stir for 5 minutes at $70 \stackrel{\circ}{ } \mathrm{C}$. After 5 minutes, the reaction was cooled to room temperature and partitioned between ether and water ( $20 \mathrm{~mL}$ each) in a separatory funnel. The layers were separated and the organic layer was washed with $1 \mathrm{~N} \mathrm{HCl}(2 \times 20 \mathrm{~mL})$. The organic layer was dried over $\mathrm{MgSO}_{4}$, filtered, and concentrated. Purification via silica gel chromatography $\quad(2.5: 1$ hexanes:EtOAc) yielded (but-3-yne-1,1diyldisulfonyl)dibenzene $\mathbf{S 1}$ (1.45 g, $4.33 \mathrm{mmol}, 43 \%$ yield) as a white solid. [ $\mathrm{R}_{\mathrm{f}}=0.05$ (3:1 hexanes:EtOAc)]; ${ }^{1} \mathrm{H}-\mathrm{NMR}\left(400 \mathrm{MHz} ; \mathrm{CDCl}_{3}\right): \delta$ 8.02-8.00 (m, 4H), $7.73(\mathrm{tt}, J=7.5$, $1.4 \mathrm{~Hz}, 2 \mathrm{H}), 7.62-7.58(\mathrm{~m}, 4 \mathrm{H}), 4.59(\mathrm{t}, J=6.1 \mathrm{~Hz}, 1 \mathrm{H}), 3.13(\mathrm{dd}, J=6.1,2.7 \mathrm{~Hz}, 2 \mathrm{H}), 1.94$ $(\mathrm{t}, J=2.7 \mathrm{~Hz}, 1 \mathrm{H})$. The remaining spectral data matched literature values. ${ }^{2}$

A $25 \mathrm{~mL}$ round bottom flask with stir bar was flame-dried and charged with sodium hydride ( $60 \mathrm{wt} \%$ in mineral oil, $93 \mathrm{mg}, 2.34 \mathrm{mmol}, 1.17$ eq.). The flask was placed under nitrogen and $13.3 \mathrm{~mL}$ of DMF was added via syringe. The flask was cooled to $0{ }^{\circ} \mathrm{C}$ in an ice/water bath and (but-3-yne-1,1-diyldisulfonyl)dibenzene S1 (669 mg, 2 mmol, 1 eq.) was added in one portion. After $\mathrm{H}_{2}$ evolution ceased, 3,3dimethylallyl bromide (0.29 mL, $2.46 \mathrm{mmol}, 1.23$ eq.) was added via syringe and the reaction was warmed to room temperature where it stirred for 24 hours. After 24 hours, the reaction was diluted with ether $(20 \mathrm{~mL})$ and quenched with $1 \mathrm{~N} \mathrm{HCl}(20$ $\mathrm{mL}$ ). The layers were shaken, separated, and the aqueous phase was extracted with ether (2x $20 \mathrm{~mL})$. The combined organics were washed with water $(25 \mathrm{~mL})$, dried over $\mathrm{MgSO}_{4}$, filtered and concentrated. Purification via silica gel chromatography (2.5:1 hexanes:EtOAc) yielded (7-methyloct-6-en-1-yne-4,4-diyldisulfonyl)dibenzene 13 (713 mg, $1.77 \mathrm{mmol}, 89 \%$ yield) as a white solid. [ $\mathrm{R}_{\mathrm{f}}=0.14$ (2.5:1 hexanes:EtOAc)]; ${ }^{1} \mathrm{H}$ NMR (400 MHz; $\left.\mathrm{CDCl}_{3}\right): \delta$ 8.12-8.10 (m, 4H), $7.69(\mathrm{t}, J=7.4 \mathrm{~Hz}, 2 \mathrm{H}), 7.56(\mathrm{t}, J=7.8 \mathrm{~Hz}$, 4H), $5.39(\mathrm{t}, J=6.5 \mathrm{~Hz}, 1 \mathrm{H}), 3.17(\mathrm{~d}, J=2.7 \mathrm{~Hz}, 2 \mathrm{H}), 3.04(\mathrm{~d}, J=6.5 \mathrm{~Hz}, 2 \mathrm{H}), 2.10(\mathrm{t}, J=$ $2.7 \mathrm{~Hz}, 1 \mathrm{H}), 1.75(\mathrm{~s}, 3 \mathrm{H}), 1.57(\mathrm{~s}, 3 \mathrm{H})$. The remaining spectral data matched literature values. $^{3}$

\footnotetext{
2 Ramón Rodríguez, J.; Castedo, L.; Mascareñas, J. L. J. Org. Chem. 2000, 65 (8), 2528.

${ }^{3}$ Muñoz, M. P.; Méndez, M.; Nevado, C.; Cárdenas, D. J.; Echavarren, A. M. Synthesis 2003, No. 18, 2898.
} 
(3-methylene-4-(prop-1-en-2-yl)cyclopentane-1,1-disulfonyl)dibenzene (14)

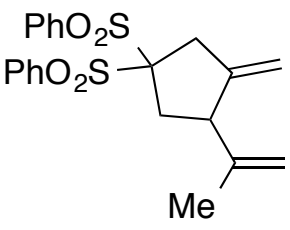

14

See below for experimental procedures used to synthesize this compound. ${ }^{1} \mathrm{H}-\mathrm{NMR}\left(400 \mathrm{MHz} ; \mathrm{CDCl}_{3}\right): \delta$ 8.09-8.03 (m, 4H), 7.75$7.70(\mathrm{~m}, 3 \mathrm{H}), 7.64-7.58(\mathrm{~m}, 4 \mathrm{H}), 4.97-4.78(\mathrm{~m}, 4 \mathrm{H}), 3.51-3.50(\mathrm{~m}$, 1H), 3.44-3.16 (m, 3H), $2.65(\mathrm{~d}, J=10.2 \mathrm{~Hz}, 2 \mathrm{H}), 1.61(\mathrm{~s}, 3 \mathrm{H})$. [Chiracel® IA column, eluting with 95:5 heptane/IPA, $0.8 \mathrm{~mL} / \mathrm{min}, 254 \mathrm{~nm} ; \mathrm{t}_{\mathrm{r}}=29.60$ and $29.30 \mathrm{~min}$ ]. The remaining spectral data matched literature values. ${ }^{4}$

2-(2-methylene-4,4-bis(phenylsulfonyl)cyclopentyl)propan-2-ol (15)

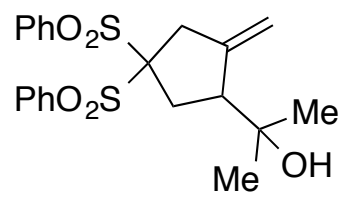

15

See below for experimental procedures used to synthesize this compound. ${ }^{1} \mathrm{H}-\mathrm{NMR}\left(400 \mathrm{MHz} ; \mathrm{CDCl}_{3}\right): \delta$ 8.10-8.01 (m, 4H), 7.75$7.69(\mathrm{~m}, 2 \mathrm{H}), 7.63-7.55(\mathrm{~m}, 4 \mathrm{H}), 5.00(\mathrm{~d}, J=12.4 \mathrm{~Hz}, 2 \mathrm{H}), 3.52-3.46$ $(\mathrm{m}, 1 \mathrm{H}), 2.85-2.69(\mathrm{~m}, 4 \mathrm{H}), 1.25(\mathrm{~s}, 6 \mathrm{H})$. [Chiracel® IA column, eluting with 80:20 heptane/IPA, $0.8 \mathrm{~mL} / \mathrm{min}, 254 \mathrm{~nm} ; \mathrm{t}_{\mathrm{r}}=17.45$ and $\left.20.82 \mathrm{~min}\right]$. The remaining spectral data matched literature values. ${ }^{4}$

Hydroxycyclization of enyne 13 with p-anisyl indenylruthenium catalyst 12 in 2-MeTHF

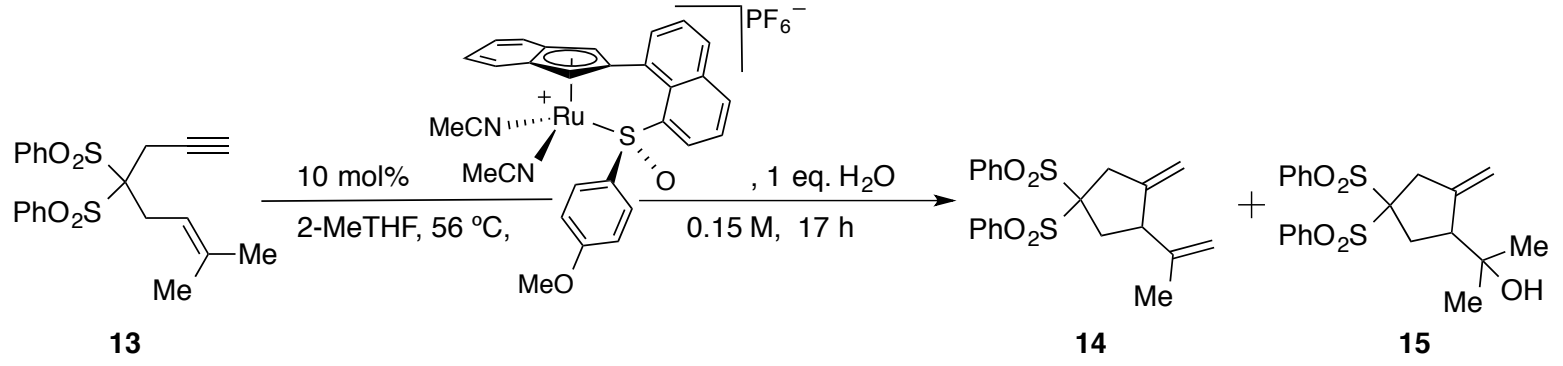

A microwave vial with stir bar was charged with enyne 13 (40 mg, 0.1 mmol, 1 eq.), indenylruthenium catalyst 12 (7 mg, $0.01 \mathrm{mmol}, 0.1 \mathrm{eq}$.), fitted with a septum, and placed under argon. 2-Methyltetrahydrofuran $(0.67 \mathrm{~mL})$ and water $(2 \mu \mathrm{L}, 0.1 \mathrm{mmol}, 1$ eq.) was added via syringe and heated to $56^{\circ} \mathrm{C}$ for $17 \mathrm{~h}$. After $17 \mathrm{~h}$, the reaction was concentrated in vacuo and purified via preparatory thin layer chromatography $2: 1$ hexanes:EtOAc). 1:10 mixture of 14 to 15 determined by NMR integration. Alcohol 15 was isolated as a white solid (10 mg, $0.02 \mathrm{mmol}, 80 \%$ yield): 84:16 e.r. of 4.43

\footnotetext{
${ }^{4}$ Muñoz, M. P.; Méndez, M.; Nevado, C.; Cárdenas, D. J.; Echavarren, A. M. Synthesis 2003, No. 18, 2898.
} 
[Chiracel® IA column, eluting with 80:20 heptane/IPA, $0.8 \mathrm{~mL} / \mathrm{min}, 254 \mathrm{~nm}$; $\mathrm{t}_{\mathrm{r}}=17.45$ and $20.82 \mathrm{~min}]$.

Hydroxycyclization of enyne 13 with p-anisyl indenylruthenium catalyst 12 in DCM

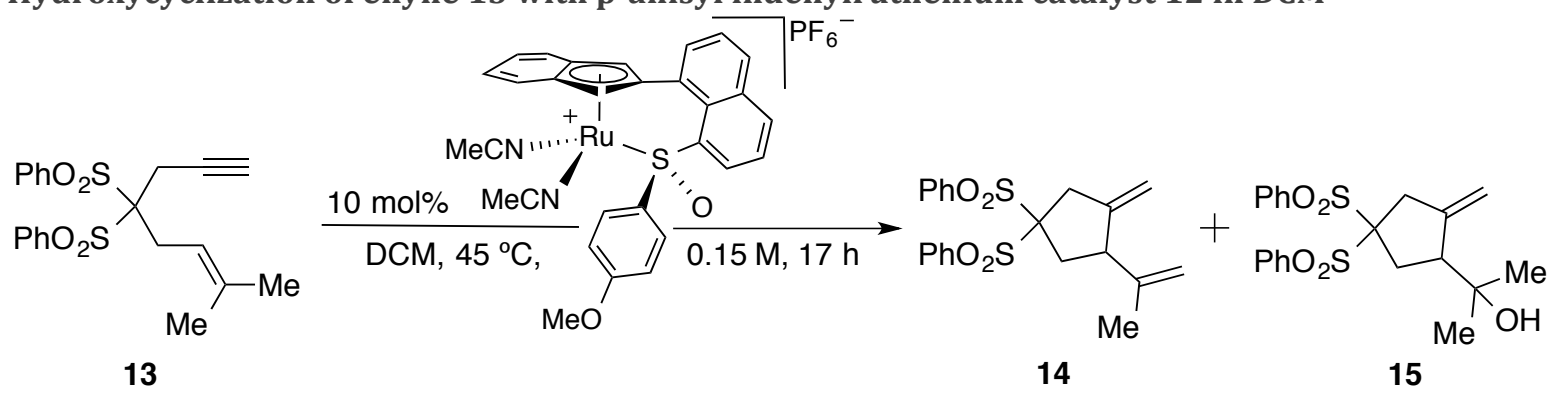

An oven-dried microwave vial with stir bar was charged with enyne 13 (12 mg, $0.1 \mathrm{mmol}, 1$ eq.), indenylruthenium catalyst 12 (12 mg, $0.01 \mathrm{mmol}, 0.1 \mathrm{eq}$.$) , fitted with$ a septum, and placed under argon. DCM (0.2 mL) was added via syringe and heated to $45^{\circ} \mathrm{C}$ for $17 \mathrm{~h}$. After $17 \mathrm{~h}$, the reaction was concentrated in vacuo and purified via preparatory thin layer chromatography (2:1 hexanes:EtOAc). 2.3:1 mixture of 14 to 15 determined by NMR integration. Diene 14 was isolated as a white solid (8 $\mathrm{mg}, 0.02$ mmol, 66\% yield): 65:35 e.r. [Chiracel® IA column, eluting with 95:5 heptane/IPA, 0.8 $\mathrm{mL} / \mathrm{min}, 254 \mathrm{~nm} ; \mathrm{t}_{\mathrm{r}}=29.60$ and $29.30 \mathrm{~min}$ ]. Alcohol 15 was isolated as a clear film (3 mg, $0.007 \mathrm{mmol}, 23 \%$ yield): 74:26 e.r. of 15 [Chiracel® IA column, eluting with 80:20 heptane/IPA, $0.8 \mathrm{~mL} / \mathrm{min}, 254 \mathrm{~nm}$; $\mathrm{t}_{\mathrm{r}}=17.45$ and $\left.20.82 \mathrm{~min}\right]$.

\section{Redox Isomerization/C-H insertion}

Methyl (E)-9-hydroxy-5,5-bis(phenylsulfonyl)dec-2-en-7-ynoate (16)

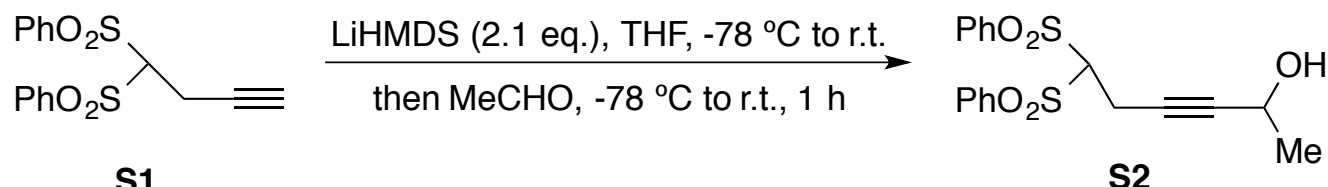

S1

S2

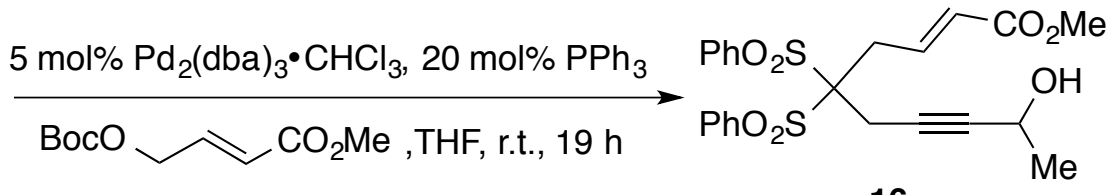

16 
A flame-dried $50 \mathrm{~mL}$ round bottom flask with stir bar was fitted with a septum and placed under argon atmosphere. A solution of alkyne $\mathbf{S} 1$ in THF $(1 \mathrm{~g}, 3 \mathrm{mmol}$, in $12.5 \mathrm{~mL}$ THF) was added to the flask via syringe and cooled to $-78{ }^{\circ} \mathrm{C}$ using a dry ice/acetone bath. A solution of LiHMDS (0.7 M in THF/hexanes, $9 \mathrm{~mL}, 2.1$ eq.) was added dropwise via syringe at $-78 \stackrel{\circ}{\circ}$. The reaction was allowed to war to room temperature and stir for 30 minutes (salts crashed out of solution at this temperature). The reaction was cooled to $-78 \stackrel{\circ}{\circ} \mathrm{C}$ again and freshly distilled acetaldehyde $(0.503 \mathrm{~mL}, 9$ mmol, 3 eq.) was added via syringe. The reaction was warmed to room temperature and stirred for 1 hour. After 1 hour, the reaction was quenched with sat.aq. $\mathrm{NH}_{4} \mathrm{Cl}$ (20 $\mathrm{mL})$. The layers were separated and the aqueous layer was extracted with ether $(2 \mathrm{x}$ $20 \mathrm{~mL}$ ). The combined organics were dried over $\mathrm{MgSO}_{4}$, filtered, and concentrated in vacuo. The crude material was purified via silica gel chromatography (1:1 hexanes:EtOAc) to yield 6,6-bis(phenylsulfonyl)hex-3-yn-2-ol S2 as a sticky white solid (454 mg, $1.2 \mathrm{mmol}, 40 \%$ yield). [ $\mathrm{R}_{\mathrm{f}}=0.19$ (1:1 hexanes:EtOAc)]; IR (thin film) $v_{\max }=$ 3522, 3066, 2924, 1584, 1448, 1421, 1324, 1312, 1266, 1148, 1077, 1021, 998, 890, $804,728,685,648,606,571,550,522 ;{ }^{1} \mathrm{H}-\mathrm{NMR}\left(400 \mathrm{MHz} ; \mathrm{CDCl}_{3}\right): \delta 8.01(\mathrm{~d}, J=8.5 \mathrm{~Hz}$, $4 \mathrm{H}), 7.72(\mathrm{t}, J=7.5 \mathrm{~Hz}, 2 \mathrm{H}), 7.60(\mathrm{t}, J=7.4 \mathrm{~Hz}, 4 \mathrm{H}), 4.60(\mathrm{t}, J=5.5 \mathrm{~Hz}, 1 \mathrm{H}), 4.27(\mathrm{q}, J=6.6$ $\mathrm{Hz}, 1 \mathrm{H}$ ), 3.14 (d, $J=6.0 \mathrm{~Hz}, 2 \mathrm{H}), 1.98-1.89$ (br s, $1 \mathrm{H}$ ), 1.28 (d, $J=6.6 \mathrm{~Hz}, 3 \mathrm{H}) ;{ }^{13} \mathrm{C}-\mathrm{NMR}$ (101 MHz, $\left.\mathrm{CDCl}_{3}\right): \delta$ 137.96, 135.12, 130.11, 129.42, 86.40, 82.21, 81.69, 58.30, 24.13, 17.08 .

An oven-dried microwave vial with stir bar was charged with $\mathrm{Pd}_{2}(\mathrm{dba})_{3} \cdot \mathrm{CHCl}_{3}$ (16 mg, $0.015 \mathrm{mmol}, 0.05$ eq.) and $\mathrm{PPh}_{3}(16 \mathrm{mg}, 0.06 \mathrm{mmol}, 0.2 \mathrm{eq}$ ) and placed under an atmosphere of argon. A solution of alcohol S2 in THF (114 mg, $0.3 \mathrm{mmol}, 1$ eq.) was added via syringe. Methyl (E)-4-((tert-butoxycarbonyl)oxy)but-2-enoate (71 mg, 0.33 mmol, 1.1 eq.) was added via syringe and the reaction was stirred at room temperature for 19 hours. After being stirred at room temperature for 19 hours, the reaction was concentrated in vacuo and purified via silica gel chromatography (1:1 hexanes:EtOAc) to yield Methyl (E)-9-hydroxy-5,5-bis(phenylsulfonyl)dec-2-en-7-ynoate 16 a sticky white solid (102 mg, $0.21 \mathrm{mmol}, 71 \%$ yield). [ $\mathrm{R}_{\mathrm{f}}=0.45$ (2:3 hexanes:EtOAc)]; IR (thin film) $v_{\max }=3514,3068,2983,2952,2255,1722,1657,1583,1477,1448,1335,1312$, 
$1284,1239,1078,1000,913,856,756,731,687 ;{ }^{\prime} \mathrm{H}-\mathrm{NMR}\left(400 \mathrm{MHz} ; \mathrm{CDCl}_{3}\right): \delta 8.05(\mathrm{~d}$, $J=8.0 \mathrm{~Hz}, 4 \mathrm{H}), 7.70(\mathrm{t}, J=7.4 \mathrm{~Hz}, 2 \mathrm{H}), 7.57$ (t, $J=7.7 \mathrm{~Hz}, 4 \mathrm{H}), 7.12(\mathrm{dt}, J=15.4,7.4 \mathrm{~Hz}$, $1 \mathrm{H}), 5.98$ (d, $J=15.4 \mathrm{~Hz}, 1 \mathrm{H}), 4.32$ (q, $J=6.6 \mathrm{~Hz}, 1 \mathrm{H}), 3.71$ (s, $3 \mathrm{H}), 3.19$ (d, $J=7.0 \mathrm{~Hz}$, 2H), 3.15 (s, 2H), 2.76-2.69 (br s, 1H), 1.29 (d, $J=6.6 \mathrm{~Hz}, 3 \mathrm{H})$; ${ }^{13} \mathrm{C}-\mathrm{NMR}(101 \mathrm{MHz}$, $\left.\mathrm{CDCl}_{3}\right): \delta 165.98,139.92,135.89,134.95,131.32,128.70,125.65,88.59,88.02,75.08$, 57.81, 51.69, 32.08, 23.75, 21.06. LR-MS (m/z): $\left[\mathrm{M}+\mathrm{H}^{+}\right]$calcd for $\mathrm{C}_{23} \mathrm{H}_{24} \mathrm{O}_{7} \mathrm{~S}_{2}$ : 477.6; found: 477.7; HR-MS (m/z): [M + $\left.\mathrm{Na}^{+}\right]$calcd for $\mathrm{C}_{23} \mathrm{H}_{23} \mathrm{NaO}_{7} \mathrm{~S}_{2}$ : 499.0861; found: 499.0861.

Methyl (E)-2-(2-(2-oxopropyl)-4,4-bis(phenylsulfonyl)cyclopentylidene)acetate (18) with chiral indenylruthenium catalyst 12

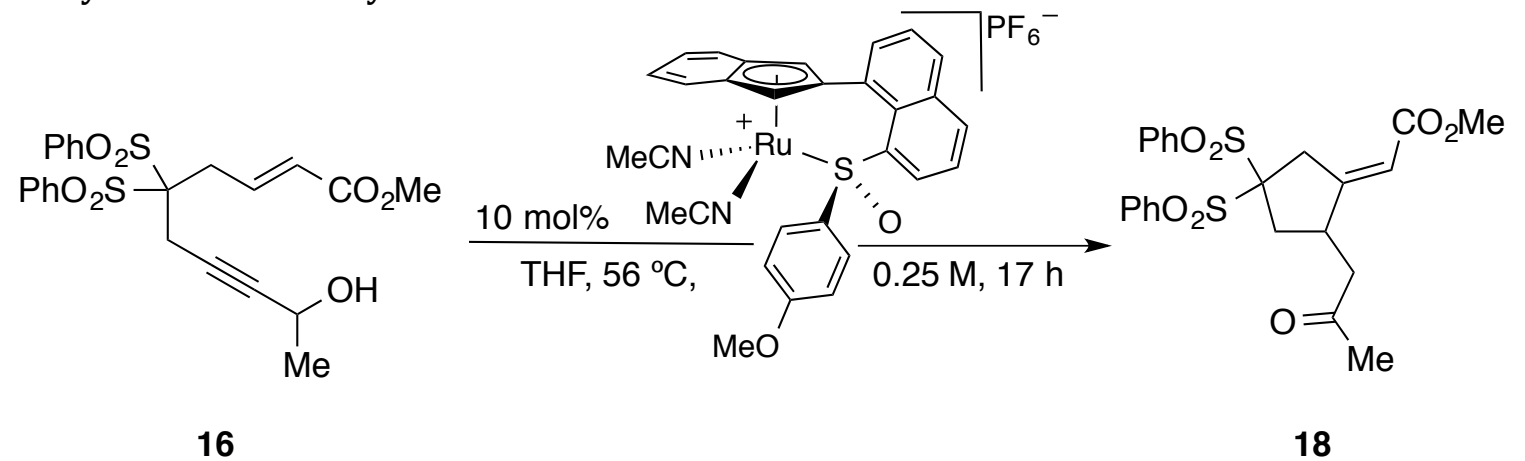

An oven-dried microwave vial with stir bar was charged with enyne 16 (48 mg, $0.1 \mathrm{mmol}, 1$ eq.), ruthenium catalyst $12(7 \mathrm{mg}, 0.01 \mathrm{mmol}, 0.1$ eq.), fitted with a septum, and placed under argon. THF (0.4 mL) is added via syringe in the desired amount (substrate $0.25 \mathrm{M}$ in indicated solvent) and allowed to stir at $56{ }^{\circ} \mathrm{C}$ for 17 hours. Conversion was determined by NMR integration of product to starting material (43\% conversion). The reaction is then concentrated in vacuo and purified via preparatory thin layer chromatography (1:1 hexanes:EtOAc). Methyl (E)-2-(2-(2oxopropyl)-4,4-bis(phenylsulfonyl)cyclopentylidene)acetate 18 isolated as a clear film. $\left[\mathrm{R}_{\mathrm{f}}=0.341: 1\right.$ hexanes:EtOAc)]; IR (thin film) $v_{\max }=3726,3704,3649,3629,3600$, 2953, 1712, 1661, 1584, 1447, 1329, 1310, 1219, 1144, 1078, 1023, 99 , 913, 727, 687, 669, 650, 605, 578, 551; ${ }^{1} \mathrm{H}-\mathrm{NMR}\left(400 \mathrm{MHz} ; \mathrm{CDCl}_{3}\right.$ ): $\delta 8.05$ (d, J = $\left.7.2 \mathrm{~Hz}, 4 \mathrm{H}\right), 7.73$ (d, J $=8.0 \mathrm{~Hz}, 2 \mathrm{H}), 7.61(\mathrm{t}, J=7.2 \mathrm{~Hz}, 4 \mathrm{H}), 5.62(\mathrm{~d}, J=2.1 \mathrm{~Hz}, 1 \mathrm{H}), 3.93-3.82(\mathrm{~m}, 2 \mathrm{H}), 3.70(\mathrm{~s}$, $3 \mathrm{H}), 3.44-3.37(\mathrm{~m}, 1 \mathrm{H}), 2.92-2.80(\mathrm{~m}, 2 \mathrm{H}), 2.64(\mathrm{dd}, J=18.3,9.1 \mathrm{~Hz}, 1 \mathrm{H}), 2.38(\mathrm{dd}, J=$ 15.3, $10.1 \mathrm{~Hz}, 1 \mathrm{H}), 2.16(\mathrm{~s}, 3 \mathrm{H}) ;{ }^{13} \mathrm{C}-\mathrm{NMR}\left(101 \mathrm{MHz}, \mathrm{CDCl}_{3}\right): \delta$ 205.65, 166.23, 162.50, 
136.42, 135.29, 134.86, 134.74, 131.20, 131.05, 128.83, 128.78, 112.82, 91.81, 51.37, 47.50, 39.82, 37.38, 35.69, 30.08; LR-MS (m/z): $\left[\mathrm{M}+\mathrm{Na}^{+}\right]$calcd for $\mathrm{C}_{23} \mathrm{H}_{24} \mathrm{NaO}_{7} \mathrm{~S}_{2}$ : 499.1; found: 499.0; HR-MS (m/z): [M + Na+] calcd for $\mathrm{C}_{23} \mathrm{H}_{23} \mathrm{NaO}_{7} \mathrm{~S}_{2}: 499.0861$; found: 499.0861; 90:10 e.r. [Chiracel® IA column, eluting with 70:30 heptane/IPA, 0.8 $\mathrm{mL} / \mathrm{min}, 254 \mathrm{~nm} ; \mathrm{t}_{\mathrm{r}}=19.55$ and $\left.22.55 \mathrm{~min}\right]$. 

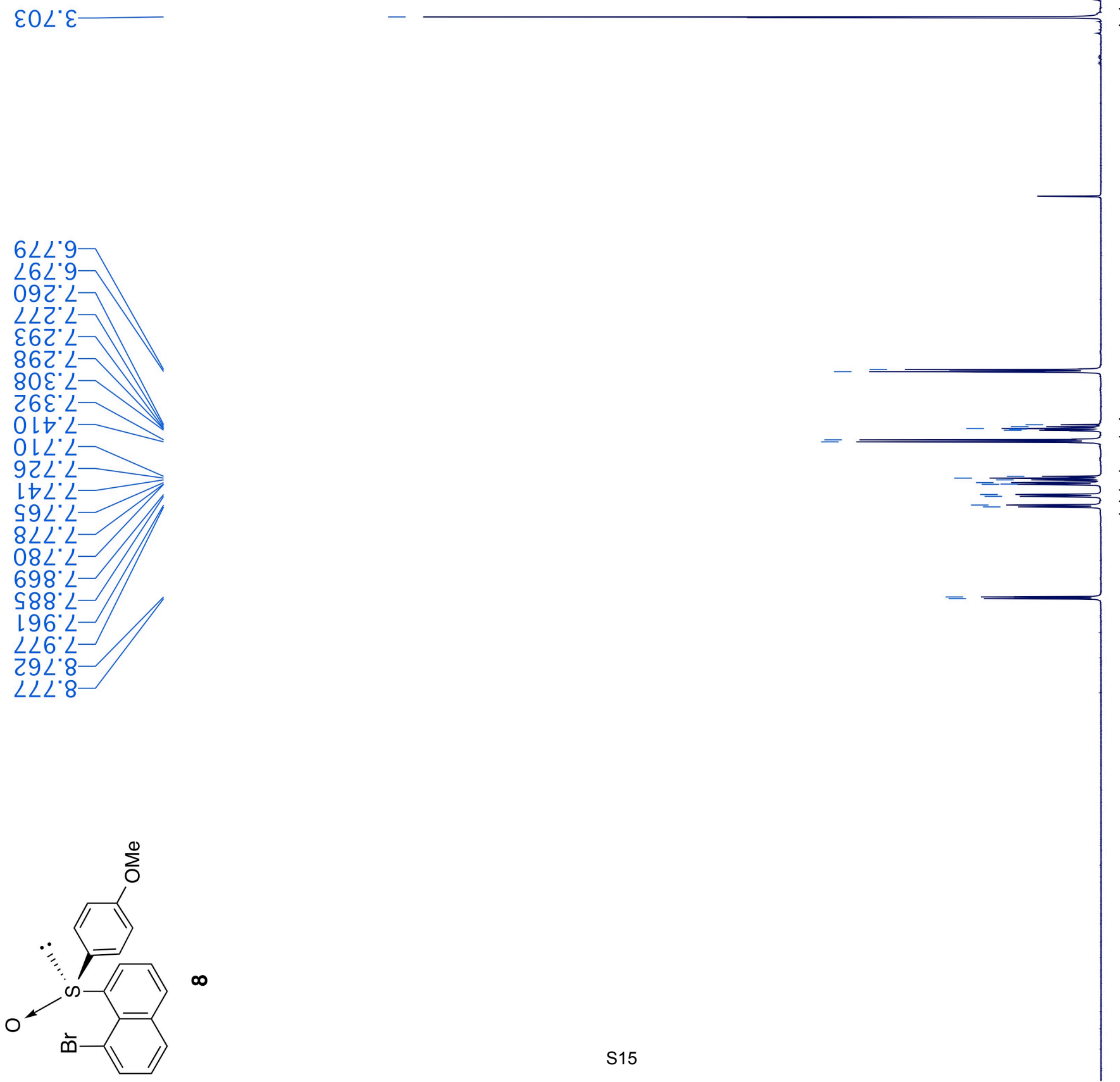


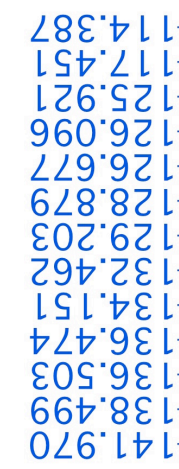

ย92 เ9L

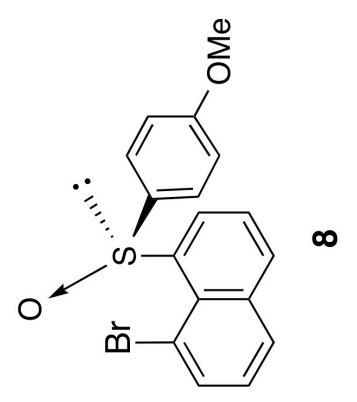



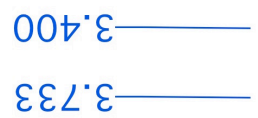

$8 \angle 0^{\circ} t$
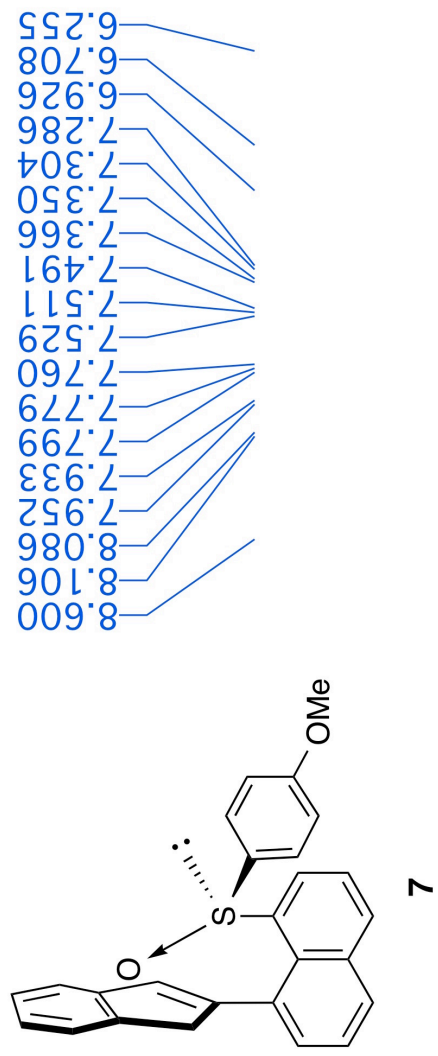
$L \angle Z \cdot S b$

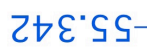

$82 L^{\circ}$
761.
$800^{\circ}$
982.
$56 \varepsilon^{\circ}$
$586^{\circ}$

ร $86^{\circ} \varepsilon 2$

हSट Sट
L9t'Sट

9SL $S 2$

2 $\angle 8.82$

126.821

$082^{\circ} 621$

62t"Zह

6S L"

५ $96^{\circ} \varepsilon t$

$886^{\circ} \varepsilon \downarrow$

しレ゙ャヤ

LSt" $\nabla$

$\neg$ ES' $|9|$
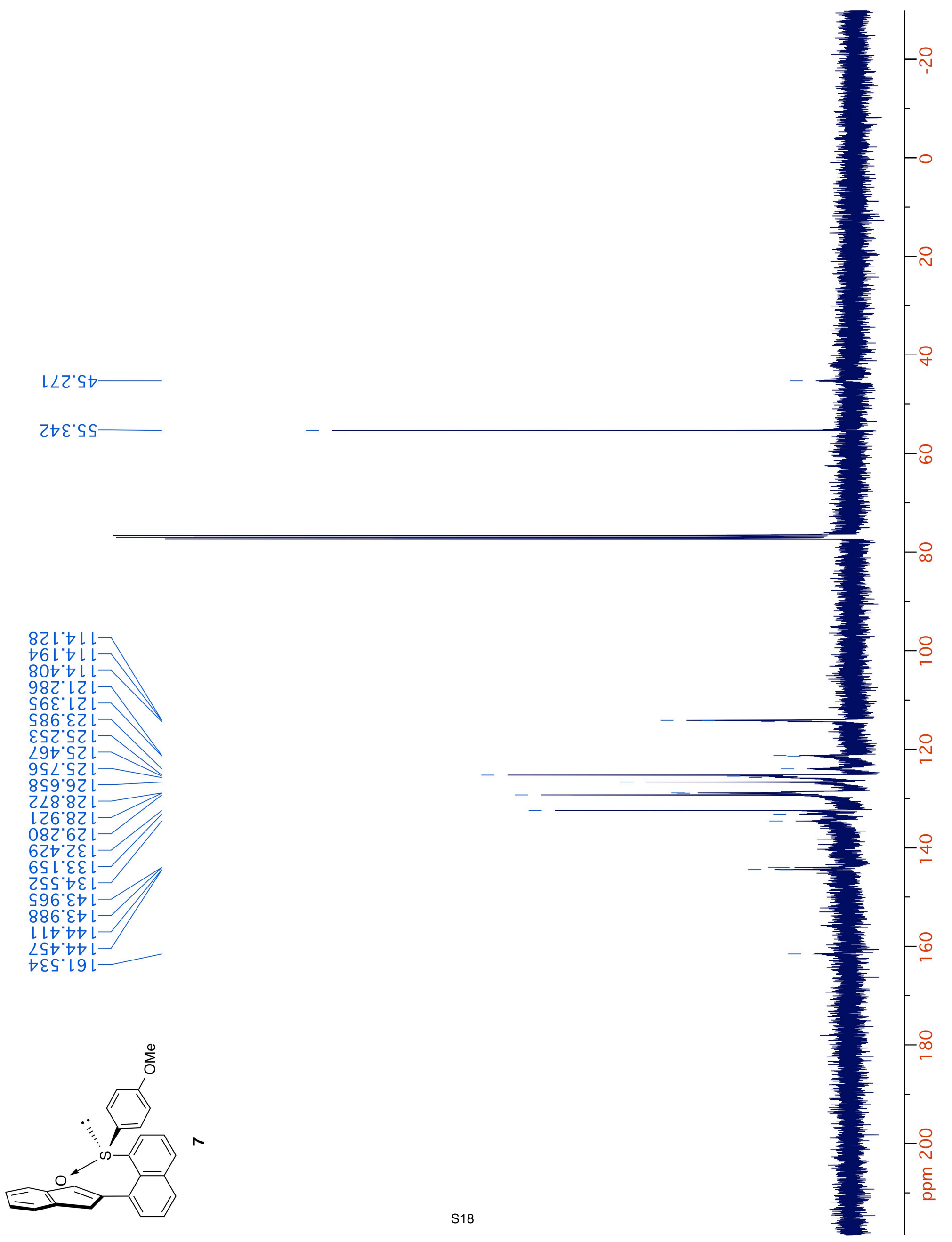

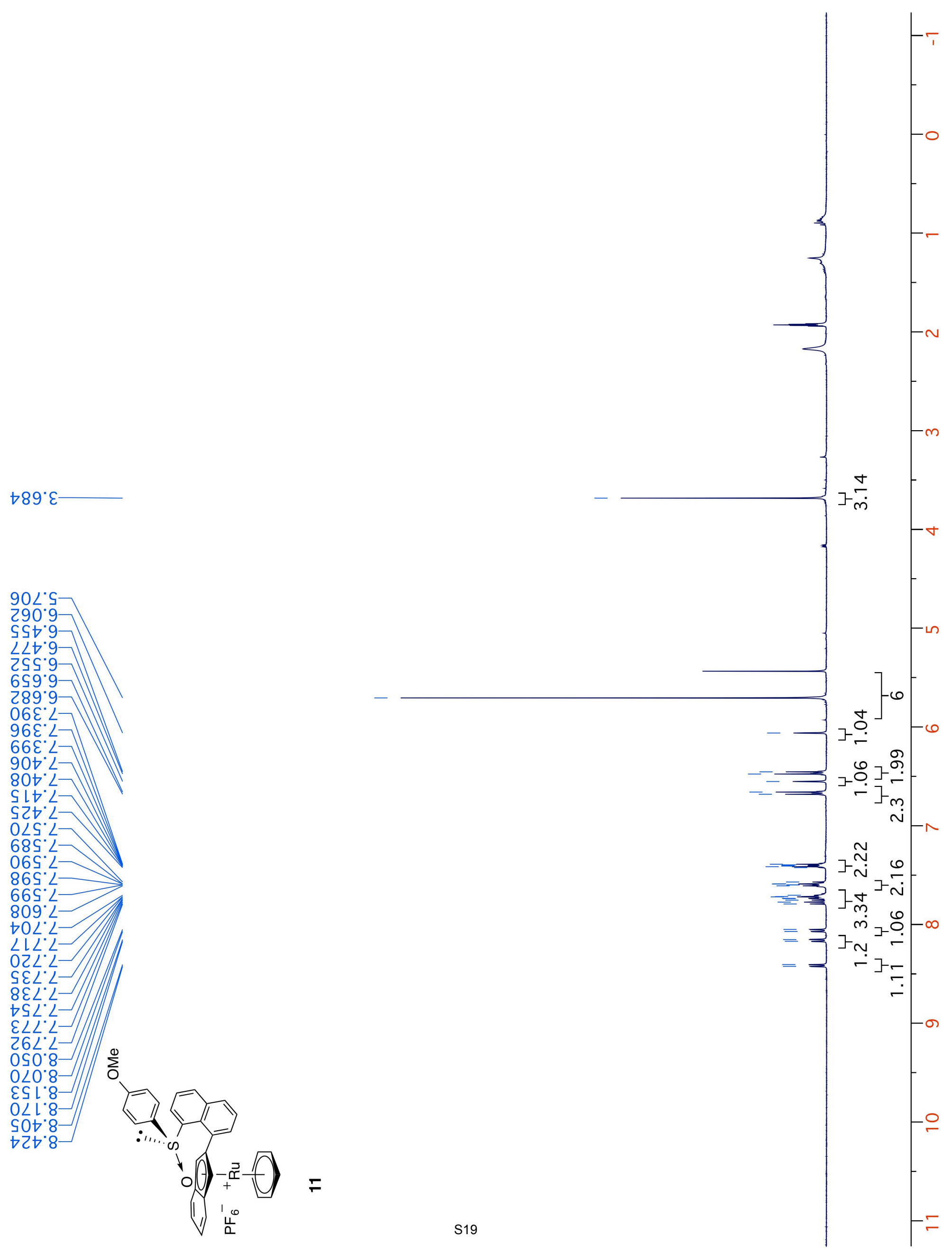


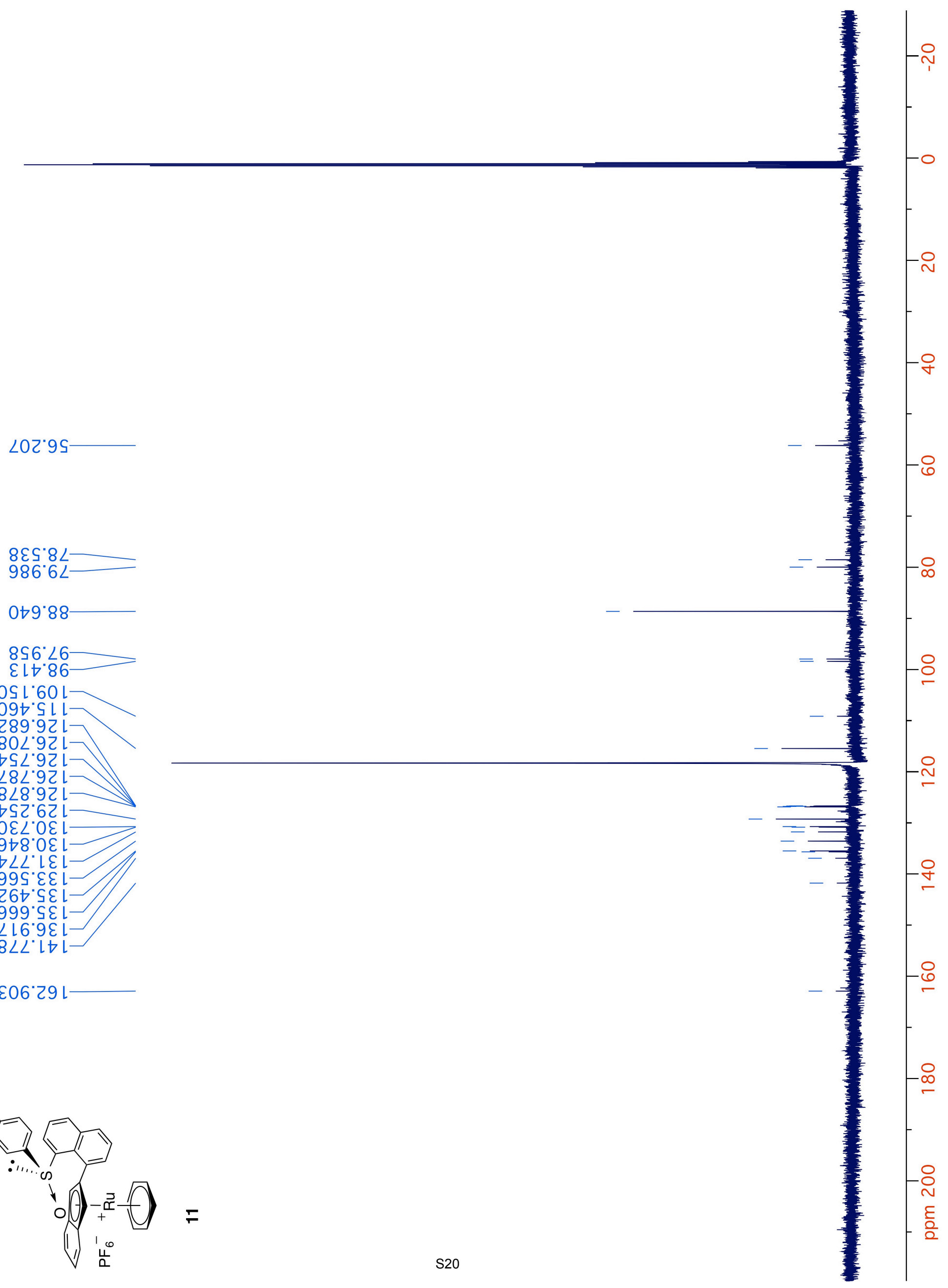




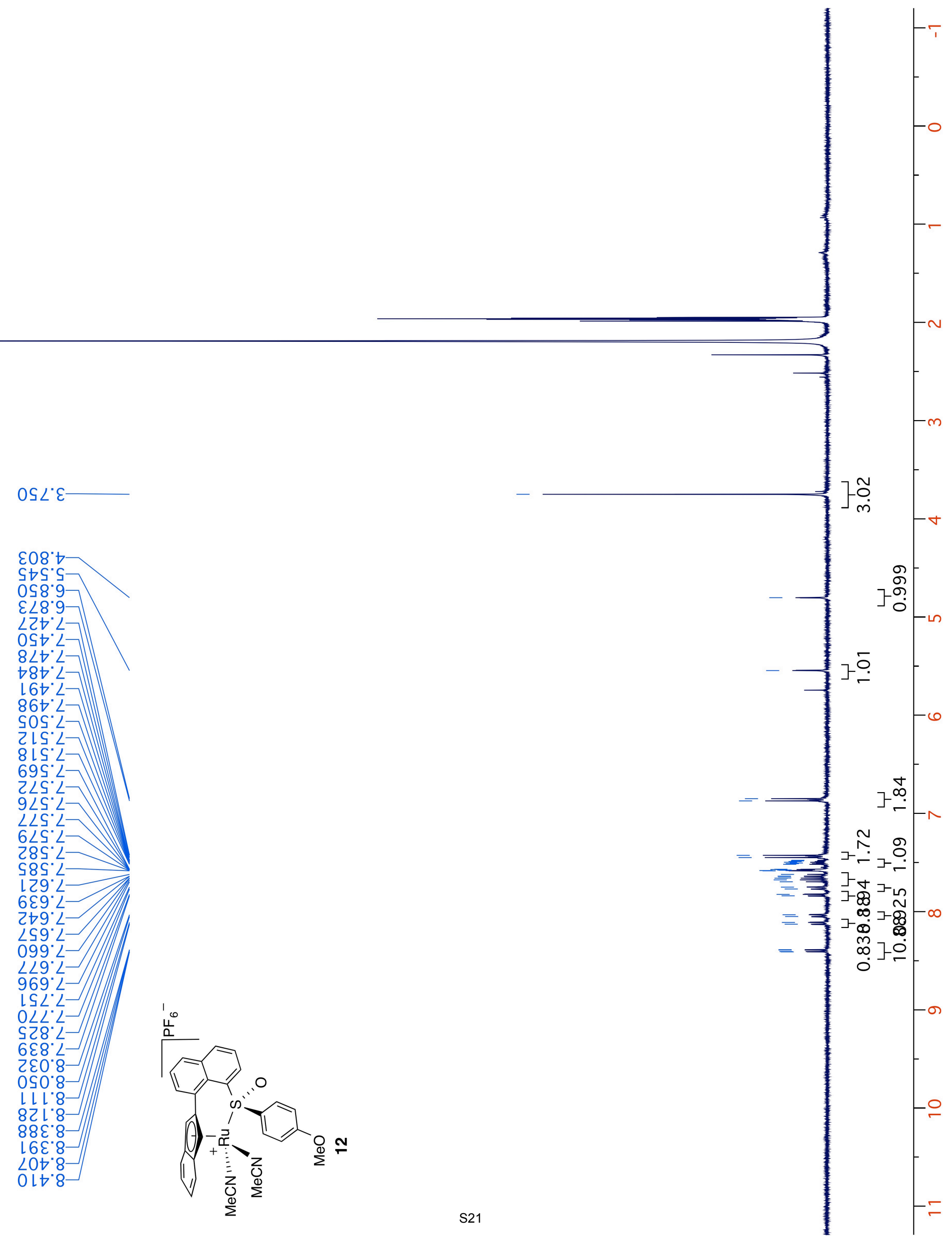




$$
i
$$


892:

SL6:
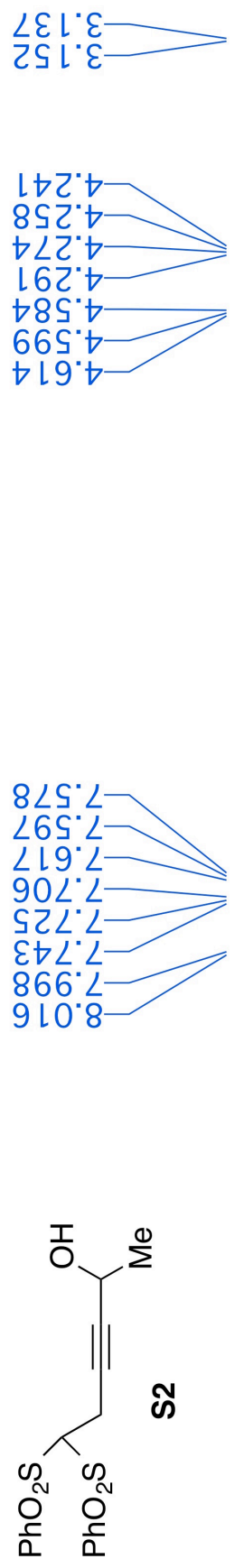

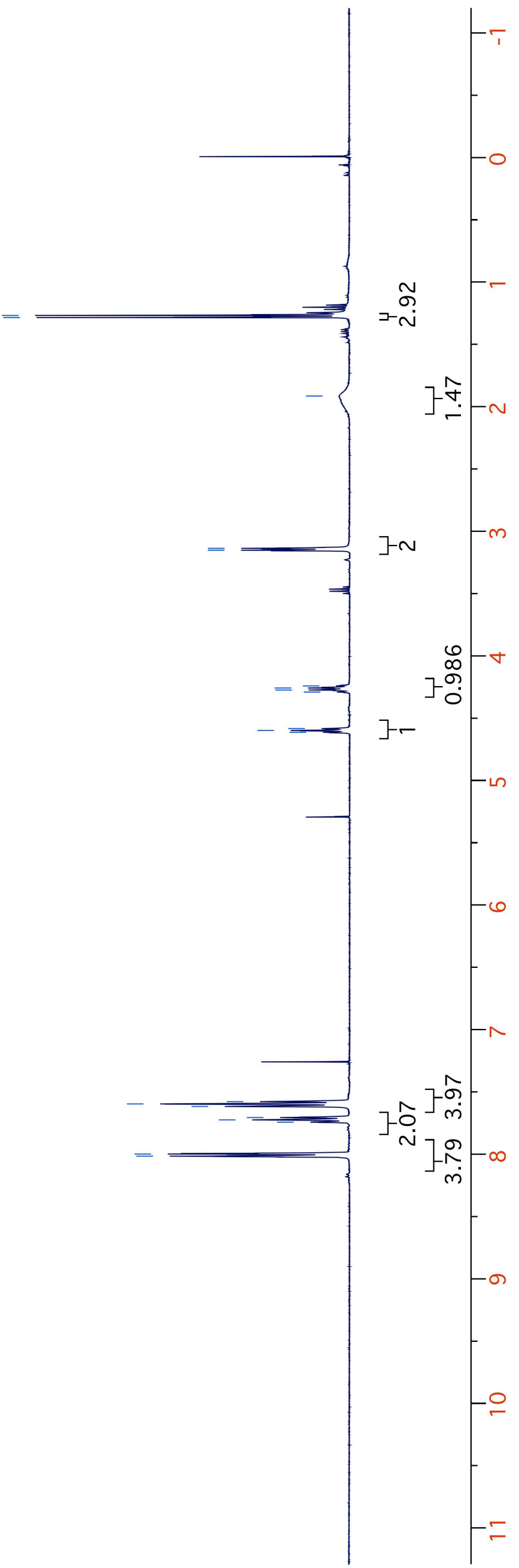


$780^{\circ} \mathrm{LL}$

$L \varepsilon l \cdot \nabla 2$

$862 \cdot 85$

S69.18-

00t"98

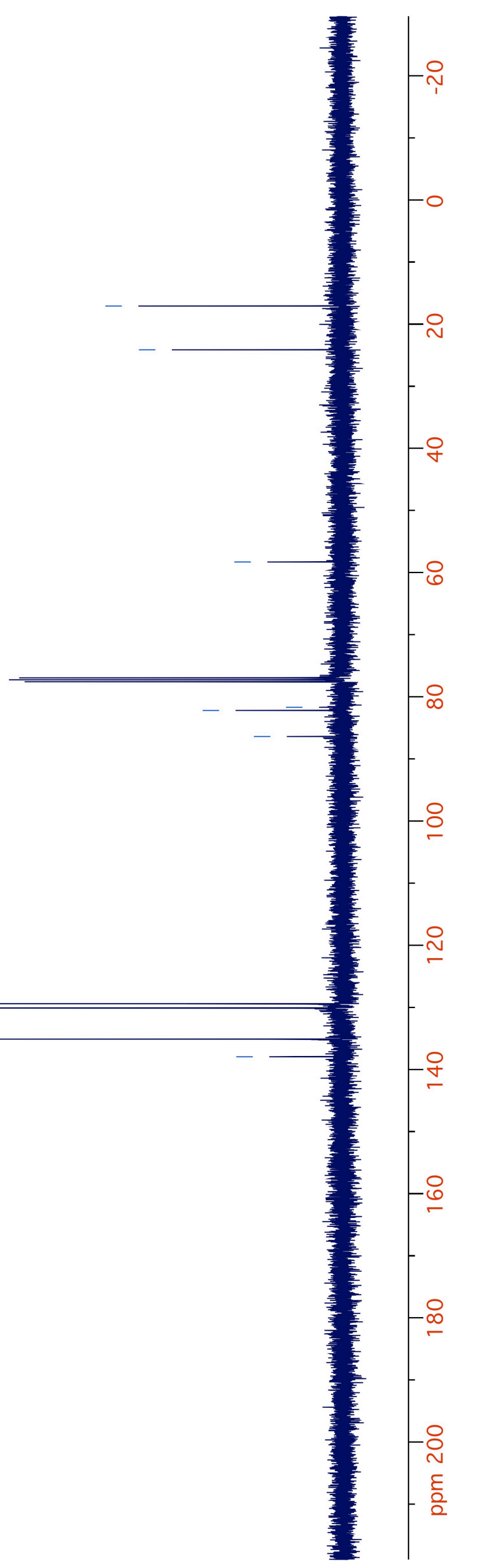


$982: L$ EOE " L

$\neg \varepsilon\llcorner\cdot 乙-$

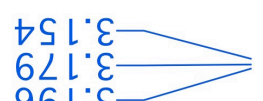
$96 l^{\circ} \varepsilon$

†LL'E$80 \varepsilon^{\prime} \downarrow$

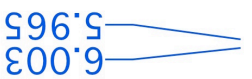

$8 \angle 0^{\circ} \mathrm{L}$ $960^{\circ} \mathrm{L}$

$9 \mathrm{LI} 2$

SE L 2

ES L'

$8 \rightarrow s^{\circ}$

$29 S^{\circ}$

$289^{\circ}$

$10 L ' \angle$

$6 \mathrm{LL} L$

$9 \varepsilon 0.8$

9S0"8

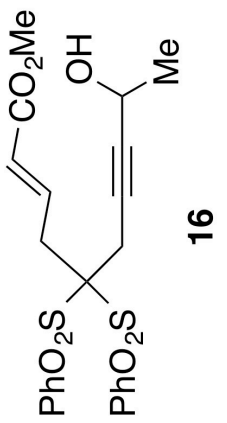

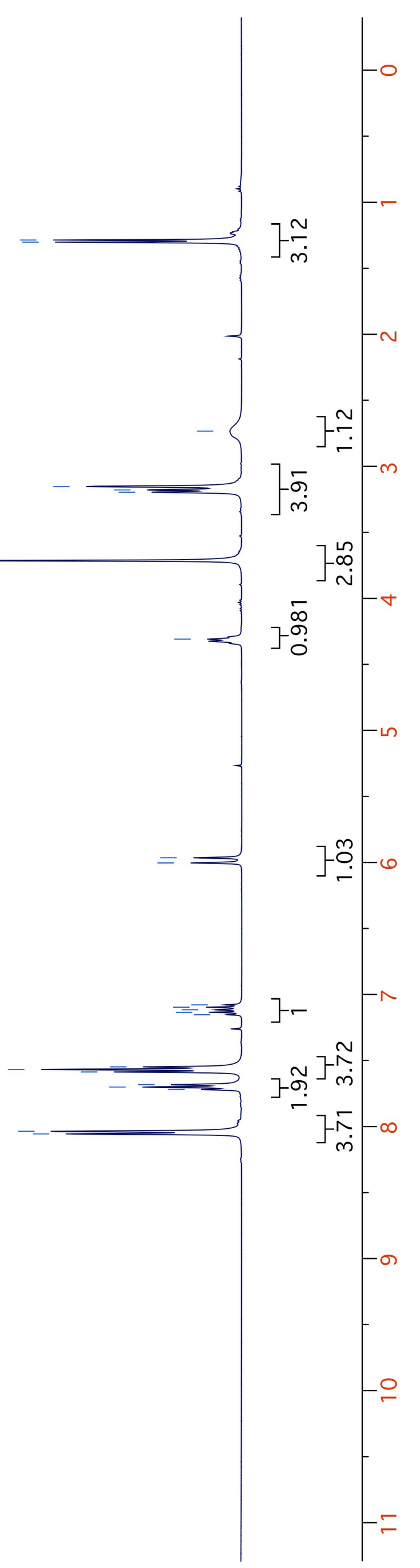



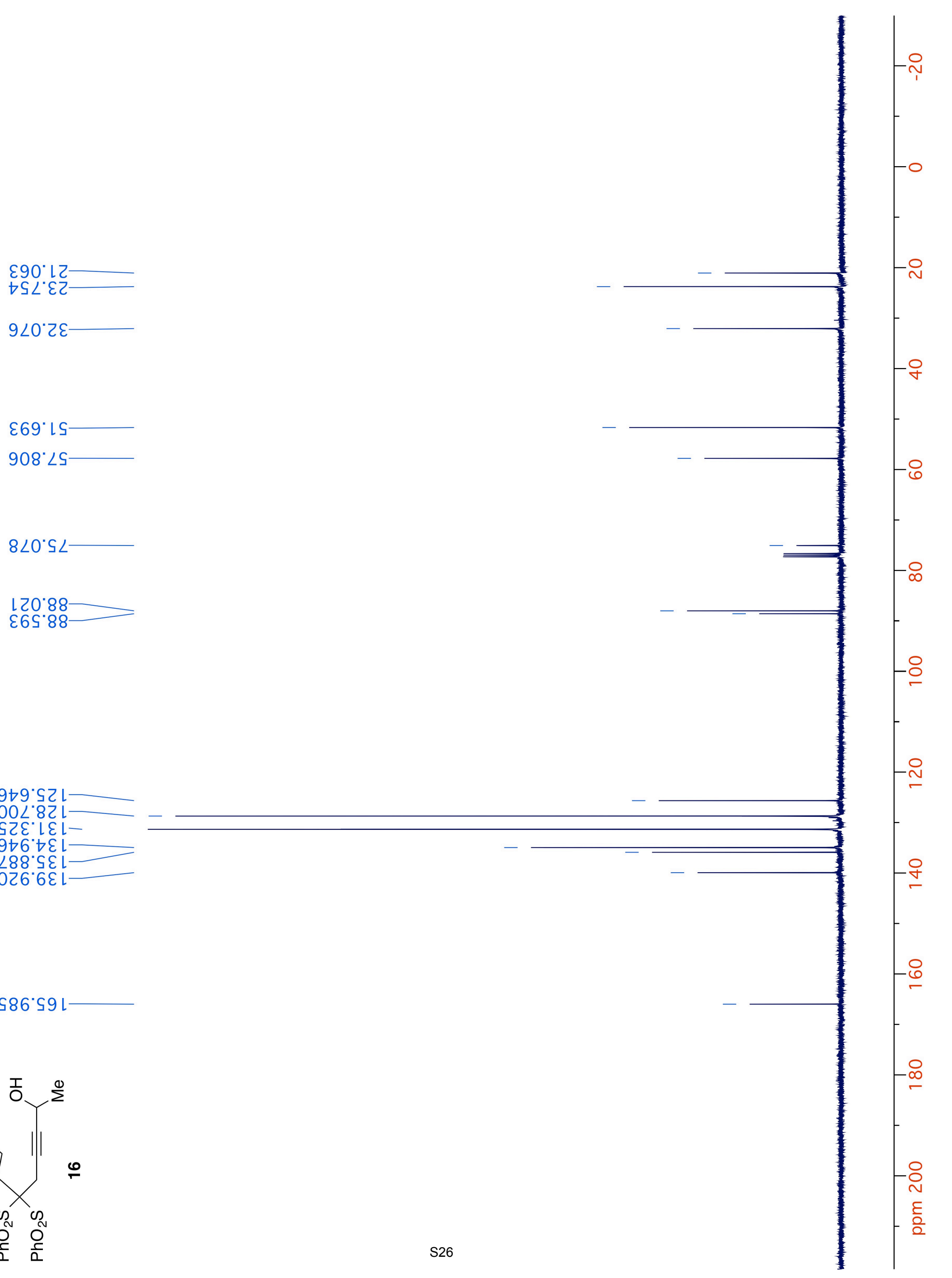


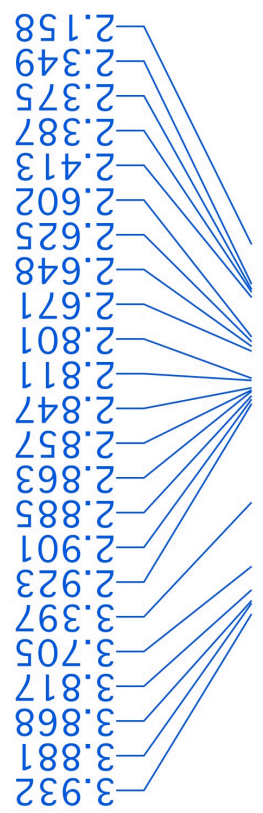

El9'S
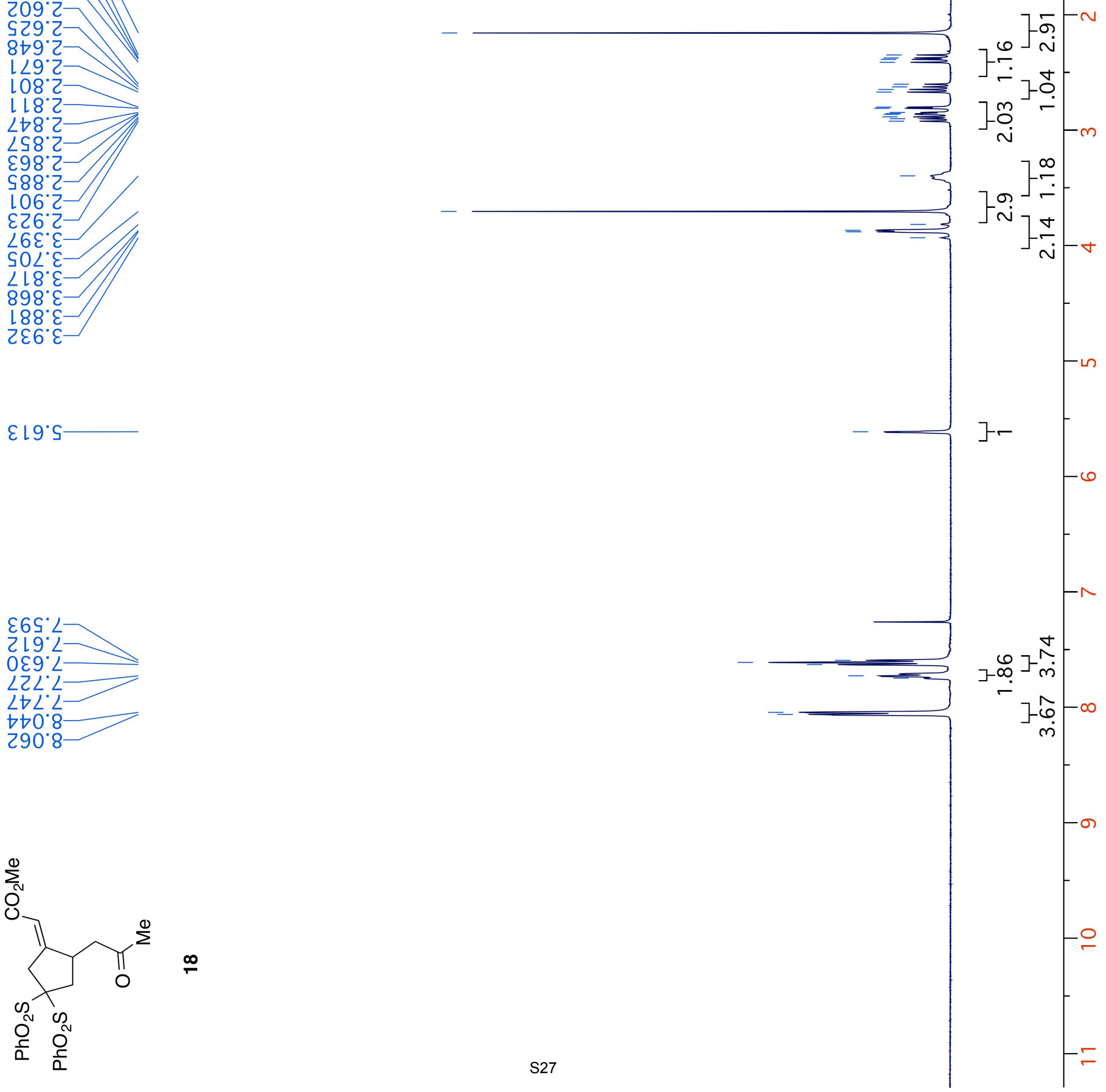

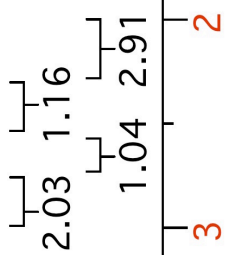

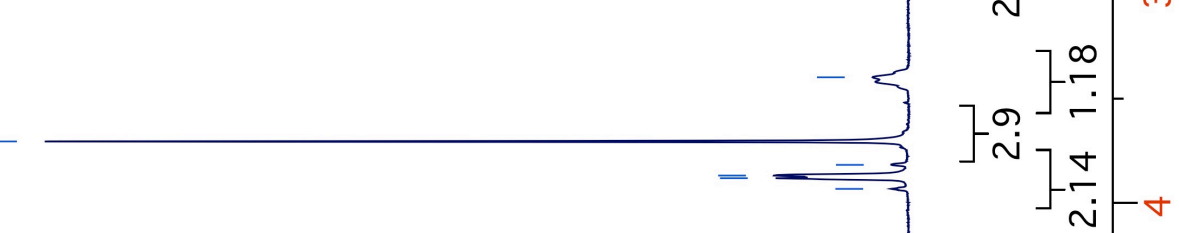


$\varepsilon 80^{\circ} 0 \varepsilon$

269. $\mathrm{S}$

E $8 \mathcal{E}^{\circ} \angle \mathcal{E}$
$\angle L 8^{\circ} 6 \varepsilon$

$00 S^{\circ} \angle t$

$\varepsilon \angle E^{\circ} L S$

S08' 16

カて8゙こレー

$78 \angle \circ 82$

टह8.82

$66 L^{\circ} L \mathcal{L}$

$6 \varepsilon L " \circ \varepsilon$

$9 S 8$ ㄴ

882' $\varepsilon$

L乙Ъ' $9 \varepsilon$ L

OOS'29

822.99 L

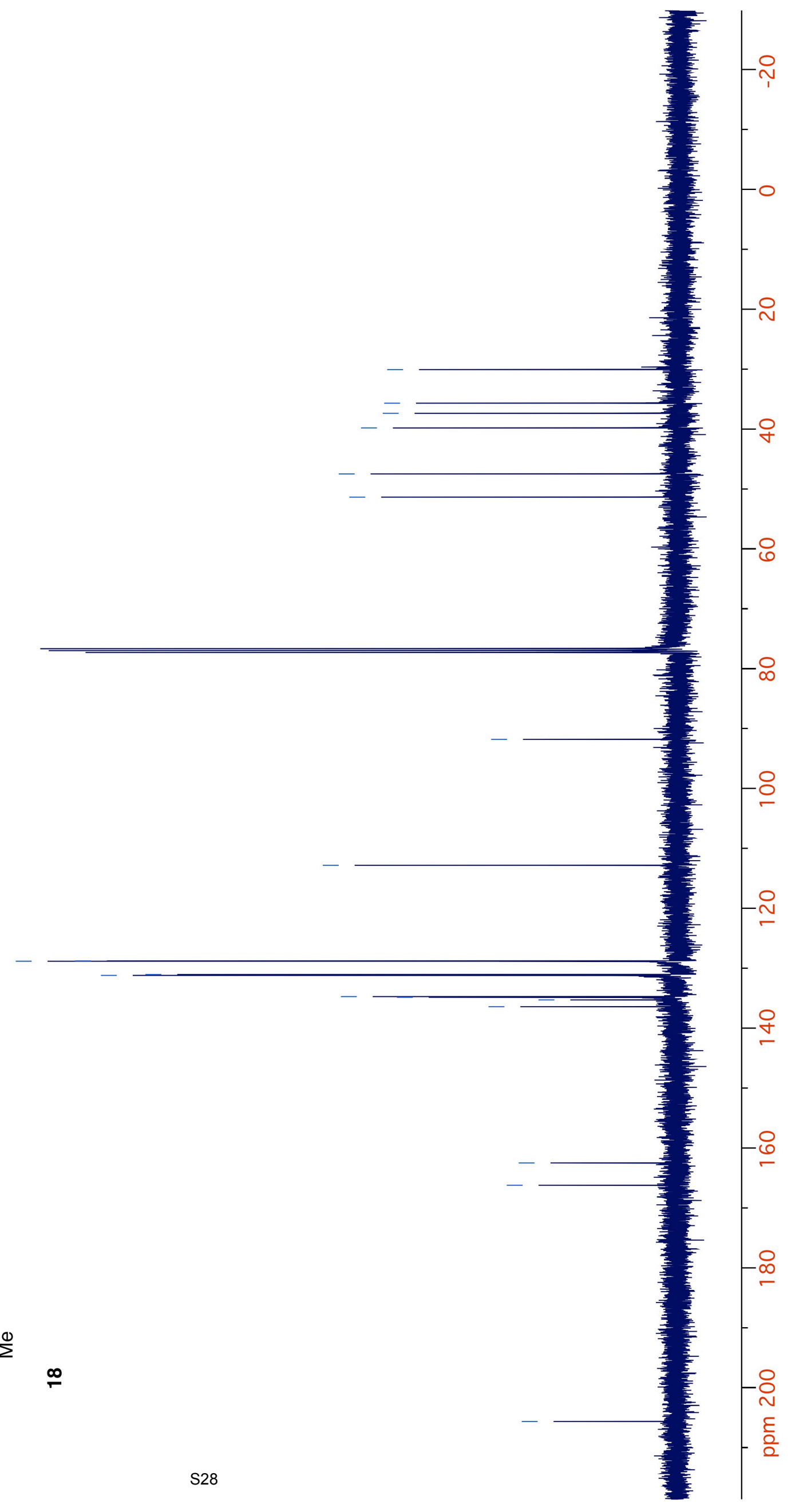

